\title{
A Study on Saving Functions for Pakistan: The Use and Limitations of Econometric Methods
}

\section{Aqdas Ali Kazmi ${ }^{1}$}

The econometric estimates of saving functions for Pakistan covering the period 1960-88 are presented and examined in this study. The choice of this period for analytical purposes was necessitated by the availability of consistent time series data on numerous microeconomic and macroeconomic variables required for estimating a wide range of econometric models of saving behaviour. The study is divided into nine sections. The introduction and the basic issues for estimating saving functions are outlined in Section 1. Section 2 delineates Sectoral Accounting Framework for defining the inter-relationship between the main components of savings, investment and national income. Section 3 outlines the econometric methods, the nature of variables used and the basic saving functions for Pakistan. Section 4 deals with the important hypotheses about private sector saving behaviour and estimates of the related saving functions. The basic rationale and estimation of public saving functions have been taken up in Section 5, while the results of foreign savings functions are presented in Section 6. The model specification and estimation of domestic saving functions and national saving functions are covered in Section 7 and Section 8 respectively. The conclusions and limitations of the study are briefly discussed in Section 9.

\section{Section 1: Saving Functions: The Basic Issues}

The phenomenon of low rate of savings in Pakistan against the background of persistently rising rates in many developing (especially Asian) countries such as India, Indonesia, Malaysia, etc. has been a challenge demanding a serious inquiry. The issue of low savings is much more complex than is generally perceived because it is an outcome of interaction of a large number of causal factors; economic, demographic, political, social, cultural and religious. Whereas some of these factors may be quantifiable, many are not, which renders the analysis of saving behaviour a difficult, if not altogether an insurmountable task.

Under many circumstances, the role of socio-political and cultural factors which are basically qualitative in nature can outweigh and counterbalance the role played by the quantifiable factors of economic and demographic origin. The econometric model-building techniques do not appear to be adequately developed to fully account for the non-measurable

\footnotetext{
${ }^{1}$ The author is Joint Chief Economist (Macro), Planning Commission, Islamabad.
} 
determinants of saving behaviour, as they interact with the observable and quantifiable factors. Moreover, the data problems for a developing country like Pakistan are perennial even in case of economic and demographic variables which are generally considered measurable.

In the absence of independent estimates of savings, a residual approach is employed to derive them. Under this approach, the total output is split between consumption and investment according to end use and then the investment-saving identity is used to derive the estimates of savings inclusive of foreign savings. The private savings is then derived as a residual after deducting the sum of foreign and public savings from national savings. The manner in which public saving is estimated is of crucial importance.

The measurement of macroeconomic macro variables like national income and investment is beset with numerous theoretical and empirical problems which cause income and as a consequence the aggregate savings to be underestimated despite the recent improvements in compilation and estimation techniques of national income accounts. The ubiquitous existence of the "underground economy", the widespread practice of the "underinvoicing" imports and "overinvoicing" exports and the prevalence of tax-evasion and the associated illegal activities when combined together, lead to substantial under-estimation of measured income and savings. Furthermore, Pakistan like many other developing countries suffers from large scale outflows of private capital which is unreported and thus adds to the measurement problems of private and national savings.

Notwithstanding these theoretical and empirical problems which are relevant to Pakistan and other developing countries, numerous estimates of saving functions for Pakistan are discussed below under the following categories:

i) Private saving functions

ii) Government or public saving functions

iii) Foreign saving functions

iv) Domestic saving functions

v) National saving functions

The basic objective in estimating these functions is to identify the most important factors and determinants which influence the saving behaviour in each sector and thus test some of the well-known hypotheses of saving behaviour. 
Considering the number of variables used in estimating the saving functions presented in this study, it is not possible to provide any comprehensive review of literature on consumption-saving behaviour, which is the most researched subject both in the developed and developing countries. A reference, however, must be made about some of the important studies which serves as the "surveys" of relevant issues and these include Abe (1977), Abraham (1964), Aghevli (1990), Ahmed (1990), Aslam (1987), Barro (1978), Boskin (1978), Feldstein (1976), Graham (1987), Goldsmith (1966), Giovannini (1985), Gupta (1970, 1987), Hubbard (1984), Kazmi (1991, 1993), Kotlikoff (1989), Qureshi (1980, 1983), United Nations (1981, 1984 and 1986), etc. Other references would be covered in the text of this study.

\section{Section 2: The Sectoral Accounting Framework and Topology of Savings}

The sectoral-accounting framework, defines the fundamental relationships of the macro-economy embodied in the national investment and sectoral saving identities. Whereas, an elaborate version of the sectoral accounting framework may be seen in Nam Sang-Woo (1990), a brief outline of the framework is presented in this section.

i) $\quad \mathrm{NI}=\mathrm{NS}+\mathrm{FS}$

This identity shows that gross fixed capital formation (i.e. NI) can be financed by national savings and the gap is filled by foreign savings (FS).

iia) $\quad \mathrm{NS}=\mathrm{HS}+\mathrm{CS}+\mathrm{GS}$

iib) $\quad \mathrm{NS}=\mathrm{PS}+\mathrm{GS}$

The identities in (ii) show that national savings can be decomposed into household saving (HS), corporate private saving (CS) and public sector saving (GS), while the sum of the first two components equals the private savings (PS).

$$
\begin{array}{ll}
\text { iii) } & \mathrm{DS}=\mathrm{NS}-\mathrm{NFI} \\
\text { or } & \mathrm{NS}=\mathrm{DS}+\mathrm{NFI}
\end{array}
$$

The relationship in (iii) indicates that domestic savings (DS) can be derived as the difference between national savings (NS) and net factor income from abroad (NFI). An important implication of (iii) is that if the level of national savings remains constant, rising NFI would be associated with lower domestic savings. Due to the predominance of the NFI factor, the domestic savings and the national savings show divergent response to 
various determinants of saving behaviours and that justifies the estimation of both the domestic saving functions and the national savings functions.

iv) $\quad(\mathrm{NFI})=(\mathrm{NFI}) \mathrm{h}+(\mathrm{NFI}) \mathrm{c}+(\mathrm{NFI}) \mathrm{g}$

According to (iv) the gross factor income from abroad is the sum of sectoral income flows from abroad accruing to household, corporate and government sectors.

va) $\mathrm{FS}=\{\mathrm{MG}-\mathrm{XG})+(\mathrm{MNFS}-\mathrm{XNFS})\}-(\mathrm{NFI})$

vb) $\quad \mathrm{FS}=\{(\mathrm{MG}+\mathrm{MNFS})-(\mathrm{XG}+\mathrm{XNFS})]-(\mathrm{NFI})$

The above identities define foreign savings in terms of trade balance, non-factor services balance and net factor income from abroad. Here MG and $\mathrm{XG}$ indicate the imports and exports of goods while MNFS and XNFS indicate the imports and exports of non-factor services respectively.

If we combine (i) to (v), we can redefine domestic savings (DS) as

vi)

$$
\mathrm{DS}=\mathrm{NI}-[(\mathrm{MG}-\mathrm{XG})+(\mathrm{MNFS}-\mathrm{XNFS})]
$$

This identity shows that if we deduct the sum of deficit on trade balance and the deficit on non-factor services from the gross fixed capital formation, we can get the value of domestic savings.

Another important identity defines the relationship between the gross domestic product (GDP) and gross national product (GNP) as:

$$
\begin{array}{ll}
\text { viia) } & \mathrm{GNP}=\mathrm{GDP}+\mathrm{NFI} \\
\text { viib) } & \mathrm{GNP}=[(\mathrm{GDP}) \mathrm{h}+(\mathrm{GDP}) \mathrm{c}+(\mathrm{GDP}) \mathrm{g}]+[(\mathrm{NFI}) \mathrm{h}+(\mathrm{NFI}) \mathrm{c}+ \\
& (\mathrm{NFI}) \mathrm{g}] \\
\text { viic }) & \mathrm{GNP}=[(\mathrm{GDP}) \mathrm{h}+(\mathrm{NFI}) \mathrm{h}]+[\mathrm{GDP}) \mathrm{c}+(\mathrm{NFI}) \mathrm{c}]+[(\mathrm{GDP}) \mathrm{g}+ \\
& (\mathrm{NFI}) \mathrm{g}]
\end{array}
$$

The most critical aspect of the macro-economic accounting system of any country for which the net factor income from abroad (NFI) is large, would be that even if the domestic savings or GDP of such an economy are relatively low, the large inflows of NFI can make a big difference by raising both the national savings and GNP. 
Since private savings (PS) indicate the sum of household savings (HS) and corporate savings (CS), we can analyse the behaviour of these components of savings in the following equations:

$$
\begin{aligned}
& \text { ix) HS }=[(\mathrm{Yd}) \mathrm{h}+(\mathrm{NFI}) \mathrm{h}] \cdot \mathrm{s}^{*} \mathrm{~h}+\mathrm{Dh} \\
& \text { x) } \quad(\mathrm{Yd}) \mathrm{h}=\mathrm{Yh}(1-\mathrm{t} * \mathrm{~h})+(\mathrm{TR}) \mathrm{h}
\end{aligned}
$$

where:

$$
\begin{aligned}
& (\mathrm{Yd}) \mathrm{h}=\text { ratio of household disposable income to GNP } \\
& \mathrm{s} * \mathrm{~h}=\text { household saving/disposable income ratio which is } \\
& \text { average propensity to save the disposable income } \\
& (\mathrm{NFI}) \mathrm{h}=\text { net factor income from abroad accruing to } \\
& \text { household sector as a ratio to GNP } \\
& \text { Dn = depreciation allowance in the household sector } \\
& \text { Yh = ratio of household (before-tax) income to GNP } \\
& \mathrm{t}^{*} \mathrm{~h}=\text { ratio of personal direct taxes to household income } \\
& (\mathrm{TR}) \mathrm{h}=\text { total net current transfers to households as share } \\
& \text { of GNP }
\end{aligned}
$$

Now the corporate savings in an economy would depend upon the corporate income after corporate transfer payments, corporate income tax and dividend payments, and the corporate capital depreciation allowance and their relationship can be expressed as

$$
\text { xi) } \mathrm{CS}=[\mathrm{Yc}+(\mathrm{TR}) \mathrm{c}]\left(1-\mathrm{t}^{*} \mathrm{c}\right)\left(1-\mathrm{div}^{*}\right)+\mathrm{Dc}
$$

Where:

$$
\begin{aligned}
& \mathrm{Yc}= \begin{array}{l}
\text { corporate income before transfer payments and } \\
\text { taxes as share of GNP }
\end{array} \\
& \mathrm{t}^{* \mathrm{c}=} \begin{array}{l}
\text { ratio of corporate income tax to corporate } \\
\text { income after transfer payments }
\end{array} \\
& \mathrm{div}^{*}=\begin{array}{l}
\text { ratio of corporate dividends (to the household } \\
\text { sector) to corporate income after transfer } \\
\text { payments and taxes }
\end{array}
\end{aligned}
$$


62 The Lahore Journal of Economics, Vol.6, No.2

Dc $=\begin{aligned} & \text { corporate capital depreciation allowances as share } \\ & \text { of GNP }\end{aligned}$

TR = transfer made to the corporate sector

If data about the components of private savings (PS) i.e. HS and CS are not available, then the private savings could be specified as following:

$$
\begin{array}{ll}
\text { xii) } & \text { PS }=(\mathrm{Yd}) \mathrm{p} \cdot \mathrm{s}^{*} \mathrm{p}+(\mathrm{NFI}) \mathrm{p} \cdot \mathrm{s}^{*} \mathrm{p}+\mathrm{Dp} \\
\text { xiii }) \quad(\mathrm{Yd}) \mathrm{p}=\mathrm{Yp}\left(1-\mathrm{t}^{*} \mathrm{p}\right)+(\mathrm{TR}) \mathrm{p}
\end{array}
$$

where:

$$
\begin{aligned}
& (\mathrm{Yd}) \mathrm{p}=\text { ratio of private disposable income to GNP } \\
& \mathrm{s}^{*} \mathrm{p}=\text { average propensity to save of the private sector } \\
& (\mathrm{NFI}) \mathrm{p}=\text { net factor income abroad of the private sector as } \\
& \text { a ratio of GNP } \\
& \mathrm{Dp}=\text { depreciation allowance of the private sector } \\
& \mathrm{t}^{*} \mathrm{p}=\text { ratio of taxes to private sector income } \\
& (\mathrm{TR}) \mathrm{p}=\text { total net current transfers (i.e. pensions, subsidies }
\end{aligned}
$$

The last component of national savings (NS) is public savings (GS) which is the sum of surplus in the revenue budget plus the surplus of the public sector enterprises. However, we include net factor income from abroad of the public sector i.e. (NFI)g into government savings, so that we finally get.

$$
\begin{aligned}
& \text { xiv) GS } \quad=\operatorname{Rg}\left(1-c^{*} g\right)+(\mathrm{NFI}) g+\mathrm{Dg} \\
& \text { xv) } \quad \mathrm{Rg}=\text { Yh.t*h }+\mathrm{t}^{*} \mathrm{c}[\mathrm{Yc}-(\mathrm{TR}) \mathrm{c}]+\mathrm{Ti} \mathrm{Yg}+(\mathrm{NFI}) \mathrm{g}+ \\
& \text { (TR)g }
\end{aligned}
$$

Where:

$$
\begin{aligned}
\mathrm{Rg} & =\text { government current revenues as share of GNP } \\
\mathrm{c}^{*} \mathrm{~g}= & \begin{array}{l}
\text { ratio of government consumption to current } \\
\text { revenues }
\end{array}
\end{aligned}
$$




$$
\begin{aligned}
(\mathrm{TR}) \mathrm{g}= & \begin{array}{l}
\text { transfers from the household and the corporate } \\
\text { sector to the government sector }
\end{array} \\
\mathrm{Dg}= & \begin{array}{l}
\text { Capital depreciation allowance of the government } \\
\text { sector as ratio of GNP }
\end{array} \\
\mathrm{Ti}= & \text { Ratio of indirect taxes to GNP } \\
\mathrm{Yg}= & \begin{array}{l}
\text { Government income from property and } \\
\text { enterprises as share of GNP }
\end{array}
\end{aligned}
$$

An understanding of these identifies within the sectoral-accounting framework is a sine qua non for developing and estimating the econometric models of saving functions (private, public, foreign, domestic and national) which is the subject matter of this study.

\section{Section 3: Econometric Methods and Basic Saving Functions}

The saving functions presented in this paper have been estimated by applying OLS (Ordinary Least Squares) because OLS gave unbiased, consistent and efficient estimates. The application of 2SLS (Two Stage Least Squares) to some of the saving functions gave results which were quite close to the OLS results as such and have been reported only in selected cases. For most of the regression equations on private, public, domestic, foreign and national saving, which have been presented in this study, the fit is good in terms of basic econometric criteria namely the value of $R 2$, the D.W. statistics and F-statistics.

The variables included in the functions have been expressed either in real per capita terms (i.e. at the constant prices of 1959-60) or in ratio terms (i.e. the nominal value of variables divided by nominal value of GNP (market prices). Whereas both these forms are commonly used in econometric research, the ratio form is sometimes given preference because this dilutes somewhat the effect of multicollinearity, autocorrelation and heteroskedasticity which generally plague the estimation of saving and consumption functions.

The range of macro and microeconomic factors affecting consumption-saving behaviour is wide and diverse. This may be seen from Table-1, which provides a profile of important factors: income and wealthrelated, demographic, fiscal, monetary, external and others which are microeconomic in nature. These factors can affect savings and consumption either directly or indirectly but what makes the problem of estimation complex is that these factors affect each other and above all most of them 
affect the level of income which is one of the primary determinants of savings in an economy. The Appendix to Table- 1 lists the symbols of various variables used in regression equations.

\section{The Basic Saving Functions}

In Table-2, basic functions for Pakistan are presented which use absolute level of income as the explanatory variable. This table provides information about marginal propensity to save (MPS), income elasticity of saving and trend growth rate in each category of private, public, domestic and national savings. According to these estimates, MPS of private sector for the period $1960-88$ is about 0.12 , income elasticity of saving is 1.27 and trend growth rate of real per capita is 3.9 per cent. The 2SLS estimates are close to OLS estimates. For the public sector MPS is 0.022 and trend growth rate is 3.1 per cent.

\section{Section 4: Estimation of Private Saving Functions and Hypothesis Testing}

The private saving functions for Pakistan estimated for the period 1960-88, with variables expressed either in ratio form or in real per capita terms, are presented in Table-3. The equations which involve variables in real per capita form carry an asterisk $(*)$ to distinguish it from the equations with variables expressed in ratio form i.e. variables as ratio of GNP. functions:

The following are the basic specifications of the private saving

i) $\quad \mathrm{PS}=\mathrm{a} 0+\mathrm{a} 1 \log (\mathrm{Y})+\mathrm{a} 2 \mathrm{~g}+\mathrm{a} 3 \mathrm{LFPR}+\mathrm{a} 5 \mathrm{M}+\mathrm{a} 6 \mathrm{P}+\mathrm{a} 7$ EXAID + a8 $\mathrm{T}+\mathrm{a} 9 \mathrm{G}+\mathrm{a} 10 \mathrm{TOT}+\mathrm{el}$

ii) $\quad \mathrm{PS}=\mathrm{b} 0+\mathrm{b} 1 \mathrm{Y}+\mathrm{b} 2 \mathrm{~g}+\mathrm{b} 3 \mathrm{LFPR}+\mathrm{b} 4 \mathrm{X}+\mathrm{b} 5 \mathrm{M}+\mathrm{b} 6 \mathrm{R} 1$ + b7 EXAII + b8 G + b9 TOT + e2

iii) $\quad$ PS $=c 0+c 1 \mathrm{Y}+\mathrm{c} 2 \mathrm{~g}+\mathrm{c} 3 \mathrm{LFPR}+\mathrm{c} 4 \mathrm{X}+\mathrm{c} 5 \mathrm{P}+\mathrm{c6}$ EXAID $+\mathrm{c} 7 \mathrm{NFI}+\mathrm{c} 8 \mathrm{CARS}+\mathrm{c} 9 \mathrm{GS}+\mathrm{e} 3$

In mode1 (i), the objective is to assess the impact on private savings (PS) of the variables such as income per capita $(\mathrm{Y})$, growth in real income $(\mathrm{g})$, labour force participation rate (LFPR), exports (X), imports (M), inflation rate $(\mathrm{P})$, external aid inflows (EXAID), taxes $(\mathrm{T})$, government expenditure and commodity terms of trade (TOT).

In specification (ii), the variable inflation rate $(\mathrm{P})$ is replaced by real interest rate (R1) with a view of determining the interest rate effects on savings. 
The model (iii), incorporates variables like net factor income from abroad (NFI), luxury consumption proxied by the number of cars registered in a year (CARS) and the government savings (GS). The last variable of government saving is included to measure the extent by which private saving is substituted by public savings.

The other models which have been estimated represent different combinations of basic explanatory variables and help in determining the robustness of key regression co-efficients.

\section{Testable Hypotheses on Saving Behaviour}

Since private savings constitute the most important component of the stock of national saving, it has been the focus of theoretical and empirical research both in developing and developed countries. Within the economic domain, a large number of demographic and economic factors determine the level of private saving as outlined in Table 1, and a fairly wide range of hypotheses have been developed which are associated with these factors. Data constraints and limitations of econometric modeling do not permit inclusion of all these variables in the functional form, nor testing of the multifarious hypotheses which are being rapidly added to economic theory of saving behaviour. The fundamental logic and linkages underlying these hypotheses have been discussed in detail in the extensive and growing literature on consumption and savings and has been summarily presented in Kazmi (1991). The objective of the present study is to concentrate on the following important hypotheses of private saving behaviour:

i) The absolute level of income is the most important determinant of private saving. (The Keynesian Hypothesis)

ii) The growth rate of real income (GNP) is positively related with the private saving. (The Modigliani-DuesenberryFriedman-Houthakker Hypothesis)

iii) Just as a rise in the dependency ratio adversely affects the savings ratio of a country, the increase in the labour force participation rate (LFPR) is expected to have a positive effect.

iv) Whereas exports raise the level of savings in a country, imports generally have the opposite effect.

v) The inflow of external capital would have a substitutive, complementary or neutral effect on the saving behaviour of a 
country depending upon its stage of economic development as well as the quantum and the terms of external capital inflows.

vi) A deterioration in the barter terms of trade would lead to lower private savings: the Laursen - Metzler - Harberberger effect.

vii) Inflationary tendencies are negatively correlated with savings in a developing country.

viii) Government spending generally raises private savings while taxes have the opposite effect.

ix) Savings are interest elastic.

x) The consumption of luxury goods, generally proxied by the number of cars registered in a country, is expected to depress the level of savings in a country.

\section{Results and Interpretation of Private Saving Functions}

The private saving functions for Pakistan estimated for the period 1960-88 as given in Table 3 help in testing some of the fundamental hypotheses of saving behaviour of the private sector in Pakistan. Since the rationale for the model specification and the choice of variables for testing the associated hypotheses has been outlined above, the discussion and the interpretation of the estimated regressions that follow would be succinct and suggestive rather than elaborate.

The estimated co-efficients of income variables (i.e. per capita income, or the growth rate of income) confirm the relevance of both the Absolute Income Hypothesis associated with Keynes as well as the MDFH (Modgiliani-Duesenberry-Friedman-Houthakker) theory of consumptionsavings which integrates the lifecycle hypothesis of Modigliani, relative income hypothesis of Duesenberry, permanent income hypothesis of Friedman and dynamic saving hypothesis of Houthakker (1965). The MDFH theory yields the rate of growth of income as the common explanatory variable as shown by Swamy (1968). The co-efficients of income variable are positive and significant at 5 per cent level in equations $3.1,3.4,3.5,3.6$ and 3.7. However in equations 3.2 and 3.3 which employ variables in ratio form, the co-efficient of income variables are positive but their level of significance is drastically reduced. This partly reflects the collinearity of the two variables and partly the sensitivity of results to model specifications. 
Among the demographic factors, the labour force participation (LFPR) is positively correlated with private savings in Pakistan. The coefficient of LFPR is positive and large and significant at 10 per cent level in equation $3.1,3.2,3.3$ and 3.6 but significant at 5 per cent level in other equations of Table-3.

The rising share of exports in the gross national income is associated with higher savings, private as well as the aggregate. The main reason for a positive link between exports and savings is that exports are generally undertaken by a select group of exporters in a country, which is assumed to have higher MPS (marginal propensity to save) as compared to MPS of the non-exporting non-capitalistic class. This is in line with the logic of Lewis model according to which capitalists belong to the saver class and wageearners to the consumer class. Further Papanek (1973) has argued that exports produce highly concentrated incomes which bring about higher savings. These conclusions are confirmed by the estimated co-efficient of export variable which is consistently positive and significant in all the equations of Table-4.

Juxtaposed to exports, rising imports lower the level of private savings. The flow of imports leads to higher income for the residents of foreign countries but lower income and lower savings to the home country residents. Furthermore, in the national income identity $\mathrm{S}-\mathrm{I}=\mathrm{X}-\mathrm{M}$, given the level of investment (I) and exports (X), higher imports (M) are directly related with lower savings (S). The inverse relationship between imports and savings is also accounted for by the degree of openness of the economy. On a priori basis, an open economy with higher imports/GNP ratio, may be more amenable to external sector fluctuations and shocks. The large open economy of Pakistan has been subjected to numerous external shocks such as oil price hike, steep decline in terms of trade and exchange rate variations, which have adversely affected the flows of savings in the country. The essence of the argument is that in a more open economy, the impact of external developments on domestic savings and investments is magnified as compared to that of a closed economy.

The negative co-efficients of $\mathrm{M}$ in numerous equations of Table-3 which are significant either at 5 per cent level or 10 per cent establish the inverse relationship between the level of imports and the savings for a developing country like Pakistan.

The inflation rate $(\mathrm{P})$ as an explanatory variable has been included in equation 3.5 to 3.7 and has come up with negative and significant coefficients thus confirming the hypothesis that private savings are adversely affected by inflation rate. 
The controversy over the impact of external capital inflows on savings remains unsettled. The impact of external capital can vary over time and among countries, depending upon the quantum and terms of capital flows and the level of development of the recipient countries. The impact of external capital inflows on savings could be substitutive reflected in the negative co-efficient, complementary, showing positive co-efficient or additive implying the parameter will not be significantly different from zero. The composition of external resources, the mode of their utilisation, their distribution between grants and loans, tied or untied, project or non-project etc. - all these elements determine the effectiveness of capital flows in domestic savings.

During, the period 1960-88, Pakistan has been a major recipient of external resources - mostly public loans and grants contracted to finance its development expenditure on an annual basis. The impact of these resources on private savings and subsequently the national savings was modeled by including EXAID i.e. the actual disbursements of foreign assistance (and loans) as an exogenous variable in the saving function. In others, the current account deficit (CAD) was chosen to represent external capital inflows. In specifications which include EXAII as the right hand variable, the co-efficient turned out to be positive and significant at 5 per cent level as in equation 3.1, 3.5, 3.6, 3.7 and in case when CAD was deployed, the co-efficient was positive, was relatively smaller in magnitude and insignificant as in equation 3.2 and 3.3. The over-all evidence, however, supports the view that external capital has been complementary to the domestic saving efforts in Pakistan and has helped in removing the foreign exchange constraint which could have been binding in the absence of external resources.

The above conclusion of the study is in line with the main findings of studies such as Rosenstien-Rodan (1961), Chenery and Strout (1966) and Chenery and Eckstein (1970). However, there are numerous studies that have come up with a negative sign for foreign capital inflows in the regression equations on savings. The important studies in this context are those of Griffin and Enos (1970), Wasow (1979), Mosley (1980), Gupta and Islam (1983), Morisset (1989), Ahmed (1990), Papanek (1973), Park (1987), Khan (1992), Mahmood (1992), Shabbir (1992) Chishti and Hasan (192), Khan and Rahim (1993), Fry (1991) and Punchamukhi, Mehta and Tadas (1987). Obviously the issue remains controversial and needs more research to settle the controversy. A summary view of the arguments associated with this controversy may be seen in Bilquees (1993).

\section{Interest Elasticity of Private Savings}


Real rate of interest is one of the most important monetary factors affecting the stock of saving in an economy. For Pakistan, positive interest elasticity of savings has been estimated by Qureshi (1981) and Khan (1989). However, Niazi (1984) using the time series data for Pakistan, Bangladesh and India has established negative correlation between interest rate and savings in all of his estimated equations. Based on different specifications of saving function and longer time series data for Pakistan, the results of Table 3 unequivocally support the hypothesis of positive effect of real interest rates on savings. In equation 3.1 to 3.3 , the co-efficient of the real rate of interest (RI) is positive and statistically significant.

To provide additional evidence of interest elasticity of consumption for Pakistan, two models of private saving and consumption in logarithmic form have been estimated and the results are reported in Table 4 (private consumption) and Table 5 (private savings).

The basic model which is fairly close to the one developed by Boskin (1978) to measure interest elasticity of saving in the U.S. is specified as following:

$$
\operatorname{Ln} C p=c 0+c 1 \operatorname{Ln} Y d-1+c 3 \operatorname{Ln} W-1+c 4 \operatorname{Ln} u+R+e
$$

Where:

$$
\begin{aligned}
& \mathrm{Cp}=\text { Real per capita consumption } \\
& \mathrm{Yd}=\text { Disposable income lagged by one year } \\
& \mathrm{W}=\text { Wealth per capita lagged by one year } \\
& \mathrm{U}=\text { Rate of unemployment } \\
& \mathrm{R}=\text { Real interest rate }
\end{aligned}
$$

This model was estimated using different definitions of real interest rates and as the results of Table 4 clearly show, private consumption in Pakistan is negatively related with real interest rates. The same model when estimated with Ln Sp i.e. (log of private savings) verified the positive interest elasticity of savings as is clear from the results given in Table-5.

To examine the effect of fiscal policies on private saving, variables such as, taxes (T), government spending (G) and government saving (GS) were included in different specifications of the saving function. It may be observed that in all equations the co-efficient of taxes (T) is negative but insignificant, $G$ (government spending) has a positive and significant co- 
efficient, while GS (government saving) consistently has negative and significant co-efficient. The last result is extremely relevant for testing the validity of debt neutrality hypothesis for a developing country like Pakistan.

Other factors which are likely to affect saving behaviour in a developing country like Pakistan are: net factor income from abroad (NFI), consumption of luxury goods proxied with the number of cars registered in a year (CARS) and the commodity terms of trade (TOT). The flow of NFI may increase, decrease or leave unchanged the level of private saving in a country depending upon the recipients' marginal propensity to consume the income from abroad. The estimated co-efficients of NFI in the private saving function for Pakistan are either positive or negative but none is significant at 5 per cent level. Therefore no definite conclusion can be drawn about the link between inflows of remittances and the private saving behaviour. It is interesting to note, however, that in the domestic saving functions which have been estimated for Pakistan and reported in Table 8, the co-efficient of NFI is consistently negative and significant, implying a clear inverse correlation between foreign remittances and domestic savings. This apparently paradoxical result can be explained when we focus on the identities of national savings and domestic savings within the sectoral accounting framework discussed earlier and the residual approach adopted in Pakistan to measure sectoral savings.

The effect of consumption of luxury goods which was proxied by the number of cars (CARS) registered on an annual basis was estimated by including CARS as one of the regressors in numerous specifications of private saving functions. Mostly the co-efficient of CARS turned out to be insignificant either with a positive or a negative sign. Only in one equation i.e. 3.8 it turned out to be negative and significant at 10 per cent level. This equation has a relatively low $\mathrm{R}^{2}$, and the value of the F-statistic is quite small. The results of equation 3.8 are not very robust, and it is difficult to verify that in case of Pakistan, the consumption of luxury goods has been a factor of reduced private savings.

Finally we analyse the effect of barter terms of trade (TOT) on private savings in Pakistan. The co-efficient of TOT is negative in most of the regressions, but it is not significant in any of the equations. One of the conclusions of the well-known Laursen-Metzler-Harberger Hypothesis is that savings are reduced on account of deterioration in barter terms of trade. The other is that this deterioration also leads to higher current account deficits in the balance of payments. The first conclusion of the Laursen-Metzler-Harberger Hypothesis is not verified from the Pakistan 
experience. However the second conclusion finds adequate support as will be discussed in the section dealing with foreign savings in Pakistan.

\section{Section 5: Estimation of Public Saving Functions}

The share of public savings in total (national) savings of Pakistan has been quite low, only 13 per cent for the period 1960-65 and 1976-80, -1.0 per cent during 1971-75 and around 10 per cent for the period 1986-88. The ratio of public savings to GNP has not only been low, it has shown significant fluctuations during the last three decades. Due to lower public sector savings but rising public sector investment, the public sector has continuously suffered a negative resource balance which as a ratio of GNP rose from 7.4 per cent during 1960-65 to 9.9 per cent during 1976-80 but declined to 8 per cent for the period 1986-88.

The need to empirically analyse the public sector saving behaviour cannot be over-emphasized. However, very limited work has been done to study government saving both in developing and developed countries, because the focus of theoretical and empirical work has mostly been private saving behaviour which is often considered as the primary determinant of aggregate (national) saving behaviour in a country. In case of Pakistan, the subject of government saving by and large has remained neglected. Therefore, estimation of public saving functions for Pakistan to identify the main determinants of government saving behaviour deserves a prominent place in the research agenda of those concerned with the abysmally low saving rate of the country.

Developing and innovating in the earlier models of government saving by Singh (1975), Jayasundera (1986) and Levy (1984), the following basic regression model was employed for estimating the public sector saving functions for Pakistan:

$$
\begin{aligned}
\mathrm{Sg}= & \mathrm{a} 0+\mathrm{a} 1 \mathrm{~g}+\mathrm{a} 2 \mathrm{X}+\mathrm{a} 3 \mathrm{M}+\mathrm{a} 4 \mathrm{P}+\mathrm{a} 5 \mathrm{EXAID}+\mathrm{a} 6 \mathrm{~T}+\mathrm{a} 7 \mathrm{Sp} \\
& +\mathrm{a} 8 \text { (TOT) }+\mathrm{U}
\end{aligned}
$$

According to this formulation of the government saving function, growth rate of real income $(\mathrm{g})$, exports $(\mathrm{X})$, imports $(\mathrm{M})$, external resources inflows (EXAID) and taxes (T) are expected on a priori basis to exert positive effect on the public sector saving while inflation rate $(\mathrm{P})$, private sector saving (SP) and deterioration in terms of trade (TOT) would have the opposite effect. This hypothesisation is, however, quite tentative. There are wide variations in the spending, taxing and saving propensities of the government all over the world. The theory of public sector saving behaviour 
remains underdeveloped and there is a universal paucity of precise hypotheses which could be tested empirically.

The co-efficient of income growth is positive in all equations but it is significant at the 10 per cent level in equation 6.4 and at 5 per cent level in equation 6.6, while the level of significance in other equations is much lower. Income growth thus appears to positively affect the saving ratio of the public sector in case of Pakistan, but this correlation is sensitive to the specification of public saving function.

Given the above caveats, the basic model of public savings given above along with some of its variants have been estimated and the results are given in Table 6 . It may be seen that the co-efficient of export variable $(\mathrm{X})$ is negative in equation 6.1 but positive in equation 6.3 and 6.6. However, since all co-efficients are insignificant, exports in Pakistan appear to exert no influence on the public saving rate. This conclusion has validity when it is realised that the private sector predominates export trade, with the result that the effect of exports on private sector saving in Pakistan is consistently positive, as shown earlier.

That imports (M) are positively correlated with public sector saving is verified from the co-efficient of $\mathrm{M}$ which is positive and significant at the 5 per cent level in all equations except equation 6.4. The positive linkage between imports and public sector saving stems from the heavy dependence of the government to raise its revenues from indirect taxes. The share of indirect taxes in total tax revenue in Pakistan has gone up from 54.0 per cent in 1959-60 to 86.7 per cent in 1987-88 while the share of trade taxes (about 90-95 per cent of which are import duties) in total tax revenues has risen from about 50 per cent in $1959-60$ to some 41 per cent in 1987-88. Some of the authorities on public finance have contended that as economic development and industrialisation proceed, income rises, the number of households entering the taxable brackets increases and the range of tax bases widens with the result that fiscal dependence of the public authorities on direct taxes increases while dependence on trade tax declines. Numerous studies using cross-country data have empirically tested and found support for the inverse relationship between fiscal dependence on indirect (trade) taxes and economic development. The most important studies which have thoroughly examined this issue are those of Lewis (1963), Musgrave (1969), Due (1970), Hinrichs (1965) and Greenway (1980, 1984).

Contrary to the findings of these empirical studies, Pakistan's reliance on trade taxes and especially import taxes to generate public revenue continued to increase during the period 1960-88 and the only 
justification for this dependence is the administrative ease with which trade taxes can be imposed and collected.

The increase in inflationary pressures in an economy reduces the purchasing power of its agents both private and public, which forces them to increase their spending level and lower their saving to command the same level of real goods and services. Inflation is thus a depressant of private and public savings. This is verified from all the equations of Table- 6 , which have negative and significant co-efficients of inflation rate $(\mathrm{P})$. The value of the estimated parameters is in a narrow range indicating that a 10 percentage points increase in inflation would decrease the public saving rate between 1.1 to 1.5 percentage points.

The response of public sector saving to external capital inflows varies over time and across countries. Utility maximisation in the public sector in each country allows room for an enormous variety of behaviour in the utilisation of aid funds which are allocated according to the preferences which public-sector decision-makers demonstrate between tax reduction, expansion of 'productive' expenditures, expansion of current nondevelopment expenditure and other competing objectives of government policy. Therefore, examples can be found for countries where the public sector has relaxed its saving effort as the external assistance from abroad has picked up. One such case is that of Egypt for which Levy (1984) has found that for the period 1960-78, an increase of 10 per cent in external assistance led to reduced public sector savings by 1.6 per cent. In a similar vein, Mosley, Hudson and Horrell (1987) derive some interesting conclusions on the effectiveness of foreign aid as they analyse empirically the issue of "fungiability" of aid money for the large number of aid-receiving developing countries over various sample periods of 1960-83. One of their findings refers to a group of six countries namely Senegal, Sri Lanka, Zaire, Upper Volta, Burundi, and Togo, which show consistently declining tax efforts and thus lower public sector saving primarily attributable to inflow of external aid.

In the case of Pakistan, the positive but significant co-efficients of EXAID in equations 6.2, 6.3, 6.4 and 6.6 and negative but insignificant coefficients in 6.1, clearly indicate the absence of any depressing role of external capital on public sector saving of Pakistan for the period 1960-88. The effect of external aid on the private sector of Pakistan has been positive as was observed in the discussion on private saving functions. The effect of aid on national saving could be expected to be positive- an issue which would be examined subsequently. 
Taxes (T) both direct and indirect are the main source of revenues and saving of the public sector in any economy. The co-efficients of tax variable in three of the equations i.e. $6.1,6.5$ and 6.6 are positive and significant at 5 per cent level. The range of estimated parameter i.e. 0.440 to 0.567 indicates that on the average, an increase of 10 per cent points in the tax/GNP ratio would raise the savings ratio by about 5 per cent points.

The issue of substitutability between private and public sector saving is a source of an important contemporary controversy relating to potency of fiscal policies. This justifies the inclusion of private saving ratio (PS) in various formulations of the public sector saving functions. The negative and consistently significant co-efficient of this variable indicates that private sector saving substitutes the public sector saving in a substantial way. However, it is important to observe that in the interaction of the two sectors, the private sector in response to higher public sector saving lowers its saving in a much larger proportion as compared to the reduction of public sector saving in response to higher private sector saving.

Even though the public sector in case of Pakistan has relatively a smaller share in the trading sector of the country, deterioration of TOT is expected to lower the public sector saving. In equations 6.4 and 6.6, the coefficients of terms of trade (TOT) are negative and significant at 10 per cent and 5 per cent level respectively. The depressing effect of (deteriorating) terms of trade on public saving is not confirmed in equation 6.5 for which the co-efficient is very small, positive and insignificant. Therefore, any generalisation about the effect of barter terms of trade on public saving would depend upon the model specification for analysing the saving behaviour of the public sector.

\section{Section 6: Estimation of Foreign Savings}

There are different approaches for analysing foreign savings (current account deficit), however, the econometric studies on foreign savings are rather limited, especially in the case of developing countries. The two classical contributions on current account analysis are by Sachs $(1981,1983)$ which focus on the determination of the 'structural' factors leading to balance of payments disequilibria of various OECD countries especially during the seventies. Through simple regression models and correlation analysis Sachs studies the relationship between current account balance and its various determinants such as income per capita, aggregate investment expenditures, change in exchange rates and oil imports in the OECD countries. After modifying Sachs' formulation of current account balance by including other relevant variables specific to Pakistan, the following models 
Aqdas Ali Kazmi 75

of current account deficit have been estimated for Pakistan for the period 1960-88:

i) $\quad \mathrm{CAD} / \mathrm{GNP}=\mathrm{a} 0+\mathrm{a} 1 \mathrm{YN}+\mathrm{a} 2 \mathrm{~g}+\mathrm{a} 3(\mathrm{INV} / \mathrm{GNP})+\mathrm{a} 4$ $(\mathrm{MOIL} / \mathrm{GNP})+5(\mathrm{TOT})+\mathrm{a} 6(\mathrm{DEF} / \mathrm{GNP})++\mathrm{e} 1$

ii) $\mathrm{CAD} / \mathrm{GNO}=\mathrm{b} 0+\mathrm{a} 1 \mathrm{~g}+\mathrm{a} 3(\mathrm{MOIL} / \mathrm{GNP})+\mathrm{a} 4 \mathrm{P}+\mathrm{a} 5$ $(\mathrm{NFI} / \mathrm{GNP})+\mathrm{a} 6 \mathrm{E}+\mathrm{a} 7(\mathrm{DEF} / \mathrm{GNP})+\mathrm{e} 2$

Where CAD is current account deficit, $\mathrm{YN}$ is nominal per capita income, $g$ is growth rate of real GNP, MOIL is import of oil in nominal rupees, $\mathrm{P}$ is the inflation rate, TOT is barter terms of trade, $\mathrm{E}$ is the nominal exchange rate, NFI is net factor income from abroad and DEF is the total budget deficit over a year, el and e 2 are regression error terms. The regression results in Table-7 represent different versions of the basic models specified above.

The two income variables i.e. YN (nominal per capita income) and $g$ (growth rate of real GNP) were included in the regression model to determine the validity of "stages of balance of payments" theory according to which as the per capita income grows, the current account deficit declines. The co-efficient of $\mathrm{YN}$ is negative but insignificant in two equations 7.1 and 7.6, while the co-efficient of $\mathrm{g}$ is negative in equations 7.1 to 7.4 but positive in equation 7.6. None of these co-efficients is significant at the traditional 5 per cent level. However, in equation 7.3 , the co-efficient of $\mathrm{Y}$ is significant at 10 per cent level. These results show that the relationship between current account deficit and the income level or income growth is rather tenuous in the case of Pakistan and does not inspire much confidence in the theory of "stages of balance of payments". This finding supports the conclusion reached by Halevi (1971), Bazdarich (1978) and Sachs (1983).

The significant, positive and large co-efficient of INV/GNP indicates that investment expenditure happens to be the most important single factor causing current account deficits in Pakistan. The predominant weight of investment expenditures in determining the size of current account deficits in Pakistan can be judged from the fact that on the average, a 10 per cent increase in investment spending brings about 5 per cent increase in the current account deficit of the country. This result is again consistent with Sachs' empirical deduction about the current account behaviour of the OECD and other developed countries. The coefficient of energy imports i.e. MOIL/GNP assumes both negative and positive signs but remains insignificant even at 10 per cent level implying therefore, that current account balance of Pakistan has by and large 
remained immune from the oil price shocks. This appears contrary to expectations, but surprisingly the current account balance of major oil importers have shown sufficient resilience against energy price hike as is econometrically established by Sachs (1983) in numerous current account regressions estimated for OECD countries.

One of the implications of Laursen-Metzler-Harberger Hypothesis is that terms of trade and current account balance are inversely related. This implication is confirmed by the negative and insignificant co-efficient of TOT which is an index of barter terms of trade of Pakistan.

The sensitivity of Pakistan's current account balance to foreign remittances the major component of NFI is evident from the significant and negative co-efficient of NFI/GNP which shows that on an average basis 10 per cent point increase in the remittances of GNP ratio decreases the current account deficit ratio by about 5 per cent points. In fact the declining ratio of $\mathrm{CAD} / \mathrm{GNP}$ is largely attributable to the rising NFI/GNP ratio especially during the Fifth Five Year Plan (1978-83) and the early years of the Sixth Plan (1983-88).

The repercussions of inflationary tendencies the on domestic economy and the external sector are generally unfavourable. The adverse effects of inflation on the private and public sector saving of Pakistan have been statistically measured and examined earlier. In case of a small open economy, the effects of inflation on its external sector can be drastic in the sense that even a small increase in domestic price could result in higher prices of exportables causing a substantive loss in international competitiveness. So there is at least one direct channe1 through which inflation can raise the current account deficit i.e. through reduction in exports. In the estimated foreign saving function for Pakistan, we find that the co-efficient of inflation rate $(\mathrm{P})$ is positive and significant in all the equations. A 10 per cent point increase in the inflation rate is associated with an increase in the current account deficit in the range of 1.1 per cent to 1.7 per cent points. Considering the large value of ' $\mathrm{t}$ ' statistics for the co-efficients of $\mathrm{P}$ which varies from a low of 2.201 in equation 7.1 to high of 4.794 in equation 7.3 , the beta-coefficient of this variable in each regression equation is expected to be comparatively higher and thus variable (P) explains a major part of variations in the current account deficit in Pakistan. The discovery of a strong positive correlation between inflation and current account suggests the paramount need of price stabilisation to avoid external imbalances of unmanageable proportions. 
The exchange rate is considered to be one of the fundamental determinants of current account balance. A depreciating exchange rate is associated with lower deficits in the current account which results from cheaper exports raising their demand and costlier imports lowering their demand. The reverse is true for the appreciating exchange rate. This hypothesised relationship is empirically verified from the experience of Pakistan's declining (depreciating) exchange especially during the last seven to eight years and the falling ratio of current account deficits to GNP. The co-efficient of exchange rate $(\mathrm{E})$ is negative and significant at the 5 per cent level in equations $7.2,7.3,7.4$ and 7.6 but significant at 10 per cent level in equation 7.5 These results unequivocally confirm the theoretical framework so frequently advanced in economic literature regarding the exchange rate variations and the current account deficits. However, the counter view that in the long term, devaluation can have adverse implications for the country and the balance of payments is presented in Kazmi (1975).

According to the conventional theory of fiscal policy, deficits of the public sector are transmitted to the external sector of the economy through larger current deficits. The debt neutrality hypothesis emphasises that fiscal policy in general and budgetary deficits in particular have no real effects such that current accounts deficits are not correlated with budget deficits. To test the diametrically opposed stances of the conventional theorists and debt neutrality proponents, the variable DEF/GNP i.e. ratios of budget deficits to GNP has been included in the foreign saving functions estimated for Pakistan. The co-efficient is positive and significant in equations 7.1, 7.4 and 7.6, which clearly supports the conventional view of fiscal policy. The positive but insignificant co-efficients of DEF/GNP in equations 7.2 and 7.3 is due to the inclusion of INV/GNP i.e investment to GNP ratio, which because of its high correlation with the budget deficits picks up the impact of the budget deficit as well. Taken all these results together, the debt neutrality proposition fails to find any support especially regarding the theoretical nexus between budget deficits and current account deficits. This result supports the findings of Zaidi (1985) in which the pooled cross-section time series data for a sample of 20 developing countries for the period 1972-80 is used and the current account balance (CA/GNP) is regressed on the budget deficit $(\mathrm{FB} / \mathrm{GNP})$ and the following equation is estimated:

$$
\begin{gathered}
(\mathrm{CA} / \mathrm{GNP})=0.66(\mathrm{FB} / \mathrm{GNP}) \\
(5.94) \\
\mathrm{R}^{-2}=0.5, \quad \mathrm{SEE}=0.038
\end{gathered}
$$


The regression equation for the developing countries thus clearly supports the proposition that there exists a positive relationship between the budget deficits and the current account deficits. This relationship is further confirmed by the estimates of the foreign saving function for Pakistan for the period 1960-88.

\section{Section 7: Domestic Saving Functions}

Domestic savings represent the stock of savings which residents of a country and its public institutions accumulate without taking into account the net factor incomes flowing from abroad. As an annual average ratio of GNP, domestic savings in Pakistan have continued to decline from a peak of 10.9 per cent during 1966-70 to 6.8 per cent during 1976-80, and 4.1 per cent during 1980-85, but slightly rose upward to a level of 5.7 per cent during 1986-88. Does this imply that the inflow of remittances has been a major factor in depressing the rate of domestic savings in the case of Pakistan? This, inter alia, would be the focal point of our enquiry while analysing the domestic saving functions given in Table 8 .

Since domestic savings are the sum of private sector and government sector savings, the effect of a given factor or a variable on the domestic savings must reflect the "net effect" that the given variable has separately on private savings and public savings. The brief discussion that follows attempts to verify this line of reasoning described as the "net effect channels" on domestic savings.

The effect of absolute level of income and real income growth is positive and significant. This is consistent with the expectations because the income effect on domestic saving summarises the dual effect of income on private sector which is positive and significant and on public sector saving, which is somewhat positive. Hence the private sector effect dominates, resulting in positive effect in the case of domestic saving. The positive effect of labour participation rate (LFPR) and exports (X) on domestic saving rate represents the net impact of these factors on the two components of the saving: private and public. The effect of imports $(\mathrm{M})$ on domestic rate is negligible in equation 8.1 to 8.3 but negative and insignificant at the 5 per cent level in equation 8.4. It appears that the negative effect of imports on private sector saving is almost counter-balanced by the positive effects on the public sector.

The effect of external capital flows (EXAID) is positive and insignificant at 5 per cent in equation 8.1 , positive and significant in equation 8.3 , positive but insignificant in equation 8.5 . In a nutshell, this 
reflects the positive effects of external aid on private saving but zero effect on public savings.

Inflation rate $(\mathrm{P})$ as an explanatory variable has been included only in equation 8.5, and has a negative and significant co-efficient which corroborates a priori expectations i.e. the net negative effect both on private sector and public sector savings.

Taxes have had no effect on private savings in Pakistan but have a positive effect on public saving, thus the net effect on domestic savings has been positive.

Similarly the interest elasticity of domestic savings is confirmed in case of equations 8.1 to 8.4 , a monotonic reflection of private sector responsiveness to real interest rate variations.

An increase in government expenditures $(G)$ has a positive effect on domestic savings, again an indicator of predominance of positive effect in the private sector over a negative effect in the public sector.

The consumption of cars reduces domestic savings which is reflected in the negative co-efficient of CARS, which is significant at the 10 per cent level.

Finally the substitutive role played by net factor incomes from abroad is reflected in negative and consistently significant co-efficients of NFI. This is a direct proof of the fact that the domestic saving efforts has been greatly relaxed on account of inflow of remittances from abroad. The regression co-efficients indicate that on the average, a 10 per cent point increase in NFI/GNP ratio has resulted in 10 to 12 per cent decline in the domestic saving ratio. Alternately, an explanation of this inverse relationship could be sought by a reference to the sectoral accounting framework discussed earlier. The saving identities clearly show that if national savings remain constant intertemporarily, the higher NFIs would imply lower levels of domestic savings.

\section{Section 8: National Saving Functions}

The national saving functions for Pakistan are given in Table 9. A brief discussion on the estimated co-efficients follows. In case of Pakistan, the share of private saving in national saving on the annual average basis has risen from 77 per cent during 1960-65 to 95 per cent during the five year period of 1966-70, almost 100 per cent during 1971-75, 87 per cent for 1976-80, 84 per cent for 1981-85 and 90 per cent for 1986-88. The predominance of private sector savings in national savings is also reflected in 
the estimation of national saving functions. This generalisation is unambiguously upheld in case of variables like income level (log Y), income growth $(\mathrm{g})$, labour force participation rate (LFPR), and exports $(\mathrm{X})$, real interest rates (R1) and government expenditure (G) all showing positive correlation with the national saving rate. However, imports $(\mathrm{M})$ and inflation rate $(\mathrm{P})$ show a negative correlation with the national saving rate even though the negative effect of imports is insignificant at 5 per cent level in some of the specifications.

The effect of external resources is positive in equation 9.1 and 9.4, significant at 5 per cent in the former and at 10 per cent in the latter. This is quite in line with the hypothesis that private sector dominates the national saving behaviour. However the hypothesis is not supported in case of equation 9.6 for which EXAID has a negative co-efficient but it is not significant at the 5 per cent level.

The effect of (deteriorating) terms of trade (TOT) and car consumption (CARS) is negative but the effect is not stable as the coefficients of these variables turn out to be insignificant in most of the cases.

\section{Section 9: Conclusions and Limitations of Study}

The preceding analysis of saving functions based on economic data for 1960-88 and multivariate specifications provide some insightful guidance about the most significant factors influencing private, public, foreign and national savings in Pakistan. The choice of a fairly wide spectrum of estimated models has been motivated by the objective of identifying some of the robust and stable parameters in which a reasonable degree of confidence could be placed. The estimation of these parameters in turn has helped in testing some of the fundamental hypotheses of saving behaviour. The following discussion summarises the empirical results.

Private sector saving behaviour in Pakistan indicates positive responsiveness not only to income (absolute level and its growth rate) but also numerous other demographic, fiscal and monetary factors such as labour force participation rate, exports, inflow of external capital, real interest rates and government spending. On the other hand, imports, rate of inflation and government saving consistently show a negative correlation with private saving. The factors such as terms of trade, consumption of luxuries (such as cars), net factor income from abroad and taxes show a negative association with private savings but this association is too weak to command a sufficient degree of confidence. 
Public sector savings are positively correlated with growth of real income but this correlation is relatively weak. The positive and consistently significant co-efficient of imports reflects the heavy dependence of the government on import duties to raise its revenues. Inflation rate and private savings are negatively correlated with public savings. The terms of trade also have a negative correlation but this correlation is sensitive to the choice of other regressors in the model. The effect of exports and external aid inflows on public saving is ambiguous.

Foreign savings or the current account deficits are positively correlated with investment expenditures, inflation rate and budge deficits but negatively correlated with barter terms of trade and exchange rate depreciation. The effect of income growth and oil imports on foreign saving is somewhat indeterminate.

The pattern of domestic savings in Pakistan depicts a positive correlation with income level and labour force participation rate, exports, gross aid disbursements, real interest rates, and government spending, but a negative correlation with inflation rate and net factor income from abroad. The large inflow of income from abroad in the form of remittances has gone entirely to raise private consumption with adverse effects on domestic savings.

Luxury consumption proxied by the number of registered cars shows a weak but negative correlation with domestic saving. However, the correlation between imports and domestic saving remains more or less indeterminate.

Finally, national savings in Pakistan show a positive correlation with income level, growth rate of income, labour force participation rate, exports, external aid inflows, real interest rate, government spending and taxes. Imports and inflation rate are negatively correlated with national savings while the consumption of cars and net factor income from abroad fail to show any determinate and stable relationship with the national saving rates. The co-efficient of terms of trade is negative but is not significant to validate the well-known Laursen-Metzler-Harberger Hypothesis. The positive correlation between taxes and national saving precludes the plausibility of the well-known "Please Effect" in the case of Pakistan.

The above conclusions of the study are based on the analysis of the saving behaviour of Pakistan for the 29 years period of 1960-88 using various specifications of regression models which serve as the principal vehicle of econometric techniques. The study, however, suffers from numerous limitations which generally characterise studies based on 
econometric methods. It is almost a truism that the results of regression equations are extremely sensitive to some of critical factors such as the choice of variables and the manner in which these variables are defined, the structure and specifications of the estimated models, the quality of data inputs and the period covered for analysis. With a change in these factors, the estimated regression equations are likely to give different results.

In the case of Pakistan, there are serious conceptual and measurement problems in estimating sectoral savings. In the residual approach of estimating national savings, which is in vogue in Pakistan, the measurement of public sector savings is of fundamental significance. Paradoxically, however, the estimation of public savings in Pakistan is based on outdated methodology and the measurement of public savings with reasonable degree of precision remains a serious constraint. This in turn casts doubts about the reliability of time series data of private savings which is the key variable in studying the saving behaviour of a developing country like Pakistan.

The regression equations which have been estimated and included in this study to depict the private, public and national saving behaviour broadly meet the parametric tests popularly used in applied econometrics. However scope does exist to improve the results such that the perennial econometric problems of multicollinearity and hetroskedesticity are minimised. For the time-series analysis, developing and examining the correlation-matrix, and applying the stationarity and cointegration tests can be instrumental in getting better results

A common inference about econometric methods suggests that the regression co-efficients serve as a general measure of "correlation of variables and do not help in determining "causality". Because of "correlation" factor in the regression equations, some results in the study would appear counterintuitive and paradoxical. Therefore, the mechanics of regression equations need to be supplemented by heuristic reasoning and detailed diagnostics to analyse the interlinkages and cause-effect relationship between economic variables.

Given the limitations which are germane to studies based on econometric methods, the saving functions developed in this study are of critical importance in identifying the main determinants of savings in the private and public sectors and thus serve as a useful tool for policy formulation both for the short-run and the long-run. 


\section{Table-1: A Profile of Factors Affecting Saving Behaviour}

\section{Income Related:}

Absolute Income (Keynes).

Relative Income(Duesenberry).

Permanent Income (Friedman).

Rate of Growth of Income

(Modigliani -Duesenbery -

Friedman - Houthakker).

\section{Wealth Related:}

Capital Stock.

Liquid Assets.

Public Debt plus Capital Stock plus Liquid Assets.

\section{Demographic:}

Population Growth Rate.

Dependency Ratio

Labour Force Participation

Rate.

Urban vs. Rural Population

Labour Force.

Industrial vs. Agricultural

Population Labour Force.

Fiscal:

Taxes.

Government Expenditures

(Consumption and Investment).

Budget Deficits.

Mode of Deficit Financing.

Public Debt.

Division of Public

Expenditures on Defence, Health, Education and

Nutrition.

\section{Monetary:}

Inflation Rate.

Real Interest Rate.

Money Supply.

Banking and Monetary

Institutions.

Development of Insurance and

Credit Markets.

\section{External Sector:}

Exports (especially the share of primary/manufactured exports in the total exports).

Imports

Exchange Rate

Net Factor Income from Abroad.

Terms of trade.

External Shocks (e.g. Oil Price

Hike).

\section{General:}

External Economic Assistance. Pattern of Luxury Consumption (proxied by the number of cars registered in a year).

Liquidity Constraints.

Differences in Family Structure.

Level of Rainfall.

Wage Structure.

Development of Stock Markets.

Provident Funds and Social

Security Schemes.

Nationalisation/Denationalisation

of Industries and Financial

Institutions..

Literacy Rate. 
84 The Lahore Journal of Economics, Vol.6, No.2

\section{Appendix to Table 1}

\section{Symbols for Regression Equations}

The following symbols are used for the variables included in the estimated regression:

(*): on a number (or a variable) indicates that the particular equation or the variable is in real per capita terms

Y: Real per capita income

PS: Private Savings

Ln: Natural log

GS: Government savings

GNP: Gross national product

DS: Domestic savings

NS: National savings

g: Growth rate of real GNP

LFPR: Labour force participation rate

$\mathrm{X}:$ Exports

M: Imports

EXAID: External capital inflow

TOT: Commodity terms of trade

DDEBT: Domestic debt

P: Rate of inflation (based on Consumer Price Index)

G: Total government expenditure on consumption and investment goods

W: Wealth 
Aqdas Ali Kazmi 85

\section{$\mathrm{U}: \quad$ Unemployment rate}

Yd: Disposable personal income

R1: Real interest rate on 6 month to one year deposits

R2: Real interest rate on one year to 3 year fixed deposits

R3: Real interest rate on deposits of three years and above

RE: Expected inflation rate

PU: Unexpected inflation rate

T: Taxes (direct plus indirect)

CAD: Current account deficit in the balance of payments

CARS: Number of cars registered in a year per thousand of population

NFI: Net factor income from abroad

Time: Time trend

MA: Monetary assets

DEF: Budget deficit

OLS: Ordinary Least Squares

2SLS: Two Stage Least Squares

AR1: First Order Autoregression Correction 
Table-2: The Basic Saving Functions for Pakistan:

The Absolute Income Model

\begin{tabular}{|c|c|c|c|c|c|c|c|}
\hline \multicolumn{8}{|c|}{ Private Savings } \\
\hline OLS & PS & $\begin{aligned}= & 1697.015 \\
& (-1.526)\end{aligned}$ & + & $\begin{array}{l}0.116 \text { GNP } \\
(29.7864)\end{array}$ & 0.969 & 2.0467 & 88.946 \\
\hline OLS & PS & $\begin{aligned}= & -18.249 \\
& (-2.047)\end{aligned}$ & + & $\begin{array}{l}0.129 \text { GNP } \\
(9.724)\end{array}$ & 0.770 & 1.593 & 94.550 \\
\hline OLS & LNps & $\begin{aligned}= & -4.064 \\
& (-4.4789)\end{aligned}$ & + & $\begin{array}{l}\text { 1.270 LnGNP } \\
(9.018)\end{array}$ & 0.724 & 1.305 & 81.325 \\
\hline $\begin{array}{l}\text { 2OLS } \\
\text { (AR1) }\end{array}$ & PS & $\begin{aligned}= & -1758.325 \\
& (-1.566)\end{aligned}$ & + & $\begin{array}{l}0.116 \text { GNP } \\
(7.752)\end{array}$ & 0.970 & 2.007 & - \\
\hline $\begin{array}{l}\text { 2SLS } \\
\text { (AR1) }\end{array}$ & PS & $\begin{aligned}= & 17.637 \\
& (-1.566)\end{aligned}$ & + & $\begin{array}{l}0.129 \mathrm{GNP} \\
(7.752)\end{array}$ & 0.669 & 1.938 & - \\
\hline \multicolumn{8}{|c|}{ Government Savings } \\
\hline OLS & GS & $\begin{aligned}= & 56.417 \\
& (0.85)\end{aligned}$ & & $\begin{array}{l}0.014 \text { GNP } \\
(5.900)\end{array}$ & 0.547 & 1.736 & 34.811 \\
\hline OLS & GS & $\begin{aligned}= & -6.417 \\
& (-1.082)\end{aligned}$ & + & $\begin{array}{l}0.222 \mathrm{GNP} \\
(2.498)\end{array}$ & 0.158 & 1.417 & 6.242 \\
\hline OLS & LnGS & $\begin{aligned}= & 1.631 \\
& (6.575)\end{aligned}$ & + & $\begin{array}{l}0.031 \text { TIME } \\
(2.245)\end{array}$ & 0.149 & - & 5.039 \\
\hline $\begin{array}{l}\text { 2SLS } \\
\text { (AR1) }\end{array}$ & GS & $=40.528$ & + & 0.014 GNP & 0.491 & 2.007 & - \\
\hline $\begin{array}{l}\text { 2SLS } \\
\text { (AR1) }\end{array}$ & GS & $\begin{aligned}= & -6.468 \\
& (0.806\end{aligned}$ & + & $\begin{array}{l}0.022 \\
(1.856)\end{array}$ & 0.077 & 2.020 & - \\
\hline \multicolumn{8}{|c|}{ Domestic Savings } \\
\hline OLS & DS & $\begin{aligned}= & 342.032 \\
& (0.204)\end{aligned}$ & + & $\begin{array}{l}0.061 \mathrm{GNP} \\
(10.335)\end{array}$ & 0.791 & 0.583 & 106.3803 \\
\hline OLS & DS & $\begin{aligned}= & 49.913 \\
& (4.642)\end{aligned}$ & - & $\begin{array}{l}0.001 \mathrm{GNP} \\
(-0.57)\end{array}$ & -0.047 & 0.655 & 0.003 \\
\hline OLS & LnDS & $\begin{aligned}= & 3.909 \\
& (34.525)\end{aligned}$ & - & $\begin{array}{l}0.003 \text { TIME } \\
(-0.529)\end{array}$ & -0.026 & 0.772 & 0.279 \\
\hline \multicolumn{8}{|c|}{ National Savings } \\
\hline OLS & NS & $\begin{aligned}= & -16.598 \\
& (-1.805)\end{aligned}$ & + & $\begin{array}{l}0.130 \mathrm{GNP} \\
(40.704)\end{array}$ & 0.983 & 1.616 & 1656.83 \\
\hline OLS & NS & $\begin{aligned}= & -28.838 \\
& (-3.049)\end{aligned}$ & + & $\begin{array}{l}0.160 \text { GNP } \\
(11.136)\end{array}$ & 0.815 & 1.059 & 124.007 \\
\hline OLS & LnNS & $\begin{aligned}= & -2.965 \\
& (-8.318)\end{aligned}$ & + & $\begin{array}{l}1.065 \mathrm{LnGNP} \\
(34.572)\end{array}$ & 0.977 & 0.963 & 1195.26 \\
\hline OLS & LnNS & $\begin{aligned}= & 3.620 \\
& (44.867)\end{aligned}$ & + & $\begin{array}{l}0.040 \text { TIME } \\
(8.521)\end{array}$ & 0.719 & 0.880 & 72.616 \\
\hline 2SLS & NS & $=\begin{aligned} & 1718.123 \\
& (-1.526)\end{aligned}$ & + & $\begin{array}{l}0.130 \mathrm{GNP} \\
(34.114)\end{array}$ & 0.977 & 1.817 & - \\
\hline
\end{tabular}


Aqdas Ali Kazmi 87

Table-3: Private Saving Functions for Pakistan: 1960-88 (OLS Estimation)

\begin{tabular}{|c|c|c|c|c|}
\hline & (1)* & (2) & (3) & (4) \\
\hline $\mathrm{C}$ & $\begin{array}{c}-242.900 \\
(-1.557)\end{array}$ & $\begin{array}{c}-0.720 \\
(-1.548)\end{array}$ & $\begin{array}{c}-0.673 \\
(-1.186)\end{array}$ & $\begin{array}{c}-1.025 \\
(-2.147)\end{array}$ \\
\hline LOG(Y) & $\begin{array}{c}0.179(\mathrm{Y}) \\
(2.899)\end{array}$ & $\begin{array}{c}0.052 \\
(1.282)\end{array}$ & $\begin{array}{c}0.047 \\
(0.913)\end{array}$ & $\begin{array}{c}0.083 \\
(1.748)\end{array}$ \\
\hline G & - & $\begin{array}{c}0.174 \\
(1.277)\end{array}$ & $\begin{array}{c}0.185 \\
(1.185)\end{array}$ & $\begin{array}{c}0.306 \\
(1.919)\end{array}$ \\
\hline LFPR & $\begin{array}{c}661.659 \\
(1.551)\end{array}$ & $\begin{array}{c}1.224 \\
(1.652)\end{array}$ & $\begin{array}{c}1.242 \\
(1.617)\end{array}$ & $\begin{array}{c}2.018 \\
(2.959)\end{array}$ \\
\hline $\mathrm{X}$ & $\begin{array}{c}0.503 \\
(2.516)\end{array}$ & $\begin{array}{c}0.855 \\
(3.236)\end{array}$ & $\begin{array}{c}0.876 \\
(2.901)\end{array}$ & $\begin{array}{c}0.560 \\
(2.275)\end{array}$ \\
\hline M & $\begin{array}{c}-0.243 \\
(-1.450)\end{array}$ & $\begin{array}{c}-0.324 \\
(-1.775)\end{array}$ & $\begin{array}{l}-0.353 \\
(-1.333)\end{array}$ & $\begin{array}{c}-0.579 \\
(-2.872)\end{array}$ \\
\hline$P$ & - & - & - & - \\
\hline EXAID & $\begin{array}{c}0.503 \\
(1.843)\end{array}$ & $\begin{array}{c}0.280(\mathrm{a}) \\
(1.230)\end{array}$ & $\begin{array}{c}0.282(\mathrm{a}) \\
(1.207)\end{array}$ & $\begin{array}{c}0.481 \\
(2.113)\end{array}$ \\
\hline $\mathrm{T}$ & $\begin{array}{c}0.335 \\
(-0.912)\end{array}$ & - & - & - \\
\hline $\mathrm{R} 1$ & $\begin{array}{c}105.876 \\
(2.148)\end{array}$ & $\begin{array}{c}0.217 \\
(2.148)\end{array}$ & $\begin{array}{c}0.210 \\
(2.338)\end{array}$ & - \\
\hline G & - & $\begin{array}{l}09.306 \\
(2.410)\end{array}$ & $\begin{array}{c}0.313 \\
(2.257)\end{array}$ & - \\
\hline TOT & - & - & $\begin{array}{c}-0.006 \\
(-0.156)\end{array}$ & $\begin{array}{l}-0.0006 \\
(-1.066)\end{array}$ \\
\hline$\overline{\mathrm{R}}^{2}$ & 0.850 & 0.491 & 0.464 & 0.3278 \\
\hline D.W & 1.726 & 1.755 & 1.746 & 1.234 \\
\hline $\mathrm{F}$ & 23.705 & 4.370 & 3.698 & 2.940 \\
\hline SSR & 2018.850 & 0.004 & 0.004 & 0.006 \\
\hline
\end{tabular}

Notes: $(*) \quad$ The starred equation is in real per capita terms.

(a) The co-efficient is for current account deficit. 
The Labore Journal of Economics, Vol.6, No.2

Table-3 (Contd.): Private Saving Functions for Pakistan: 1960-88 (OLS Estimations)

\begin{tabular}{|c|c|c|c|c|}
\hline & (5) & (6)* & $(7)^{*}$ & (8) \\
\hline $\mathrm{C}$ & $\begin{array}{c}-0.781 \\
(-1.813)\end{array}$ & $\begin{array}{c}-171.514 \\
(-1.485)\end{array}$ & $\begin{array}{c}-118.384 \\
(-2.292)\end{array}$ & $\begin{array}{c}-0.909 \\
(-1.114)\end{array}$ \\
\hline LOG(Y) & $\begin{array}{c}0.076 \\
(1.829)\end{array}$ & - & $\begin{array}{l}- \\
-\end{array}$ & $\begin{array}{c}0.109 \\
(1.173)\end{array}$ \\
\hline Y & - & $\begin{array}{c}0.121 \\
(2.687)\end{array}$ & $\begin{array}{c}0.122 \\
(2.442)\end{array}$ & - \\
\hline G & $\begin{array}{l}- \\
-\end{array}$ & - & $\begin{array}{c}119.678 \\
(1.681)\end{array}$ & $\begin{array}{l}- \\
-\end{array}$ \\
\hline LFPR & $\begin{array}{c}1.238 \\
(2.122)\end{array}$ & $\begin{array}{r}487.425 \\
(1.590)\end{array}$ & $\begin{array}{c}504.953 \\
(2.184)\end{array}$ & $\begin{array}{c}0.734 \\
(0.786)\end{array}$ \\
\hline $\mathrm{X}$ & $\begin{array}{c}0.301 \\
(2.067)\end{array}$ & $\begin{array}{l}0.3178 \\
(2.258)\end{array}$ & $\begin{array}{c}0.303 \\
(1.997)\end{array}$ & $\begin{array}{c}0.850 \\
(3.146)\end{array}$ \\
\hline M & - & - & - & - \\
\hline$P$ & $\begin{array}{c}-0.204 \\
(-4.252)\end{array}$ & $\begin{array}{c}-130.707 \\
(-4.406)\end{array}$ & $\begin{array}{c}-119.507 \\
(-4.119)\end{array}$ & $\begin{array}{c}-0.263 \\
(4.184)\end{array}$ \\
\hline EXAID & $\begin{array}{c}0.314 \\
(2.085)\end{array}$ & $\begin{array}{c}0.305 \\
(1.795)\end{array}$ & $\begin{array}{c}0.290 \\
(1.787)\end{array}$ & $\begin{array}{c}-0.263 \\
(-1.184)\end{array}$ \\
\hline GS & $\begin{array}{c}-0.896 \\
(-4.157)\end{array}$ & $\begin{array}{c}-0.849 \\
(-4.168)\end{array}$ & $\begin{array}{l}-0.829 \\
(-4.85)\end{array}$ & - \\
\hline NFI & $\begin{array}{c}-0.328 \\
(-0.164)\end{array}$ & $\begin{array}{c}-0.073 \\
(-0.475)\end{array}$ & - & $\begin{array}{c}-0.075 \\
(-0.208)\end{array}$ \\
\hline TOT & - & - & - & $\begin{array}{c}-0.001 \\
(-0.238)\end{array}$ \\
\hline CARS & $\begin{array}{l}- \\
-\end{array}$ & $\begin{array}{l}- \\
-\end{array}$ & $\begin{array}{c}1.957 \\
(-0.234)\end{array}$ & $\begin{array}{c}-0.002 \\
(-1.720)\end{array}$ \\
\hline $\mathrm{T}$ & $\begin{array}{l}- \\
-\end{array}$ & - & $\begin{array}{l}- \\
-\end{array}$ & $\begin{array}{c}-0.001 \\
(-0.238)\end{array}$ \\
\hline$\overline{\mathbf{R}}^{2}$ & 0.64 & 0.913 & 0.920 & 0.496 \\
\hline D.W. & 1.660 & 1.878 & 1.970 & 2.105 \\
\hline $\mathrm{F}$ & 8.388 & 43.118 & 41.421 & 3.42 \\
\hline SSR & 0.003 & 1169.010 & 1022.900 & 0.004 \\
\hline
\end{tabular}


Aqdas Ali Kazmi 89

Table-4: Interest Elasticity of Private Savings in Pakistan

Dependent Variable:

Log PC (Private Consumption)

\begin{tabular}{lcc}
\hline & OLS & 2SLS(ARI) \\
\hline C & (1) & $(2)$ \\
\hline \multirow{2}{*}{ Ln Yd } & 0.388 & 0.411 \\
& $(0.576)$ & $(0.499)$ \\
Ln Yd(-1) & 0.489 & 0.522 \\
& $(2.875)$ & $(3.72)$ \\
1n W(-1) & 0.344 & 0.331 \\
& $(2.014)$ & $(2.262)$ \\
Ln U & 0.103 & 0.080 \\
& $(0.906)$ & $(0.575)$ \\
R1 & 0.063 & 0.080 \\
& $(2.703)$ & $(0.575)$ \\
R2 & -0.151 & -0.163 \\
R3 & $(-2.083)$ & $(-2.108)$ \\
$\bar{R}^{2}$ & - & - \\
D.W. & - & - \\
F & 0.990 & 0.995 \\
SSR & 1.300 & 1.764 \\
\hline
\end{tabular}


90 The Lahore Journal of Economics, Vol.6, No.2

Table-5: Interest Rate Elasticity of Private Savings in Pakistan: 1960-88 Dep: Var: Log (PS)

\begin{tabular}{|c|c|c|c|c|c|}
\hline & ARI & ARI & ARI & $\begin{array}{l}\text { 2SLS } \\
\text { (ARI) } \\
\end{array}$ & ARI \\
\hline & (1) & (2) & (3) & (4) & (5) \\
\hline $\mathrm{C}$ & $\begin{array}{c}-2.662 \\
(-5.705)\end{array}$ & $\begin{array}{c}-2.590 \\
-(5.692)\end{array}$ & $\begin{array}{c}-6.783 \\
(-1.250)\end{array}$ & $\begin{array}{c}-6.020 \\
(-1.122)\end{array}$ & $\begin{array}{c}-6.889 \\
(-1.115)\end{array}$ \\
\hline LnYd & $\begin{array}{c}1.031 \\
(25.778)\end{array}$ & $\begin{array}{c}1.022 \\
(26.119)\end{array}$ & $\begin{array}{c}2.810 \\
(2.500)\end{array}$ & $\begin{array}{c}2.819 \\
(2.497)\end{array}$ & $\begin{array}{c}2.818 \\
(2.407)\end{array}$ \\
\hline LnyD-1 & - & - & $\begin{array}{c}-1.455 \\
(-1.338)\end{array}$ & $\begin{array}{c}-1.426 \\
(-1.300)\end{array}$ & $\begin{array}{c}-1.467 \\
(-1.267)\end{array}$ \\
\hline LnW-1 & - & - & $\begin{array}{c}0.224 \\
(0.224)\end{array}$ & $\begin{array}{c}0.086 \\
(0.095)\end{array}$ & $\begin{array}{c}0.239 \\
(0.235)\end{array}$ \\
\hline $\mathrm{LnU}$ & - & - & $\begin{array}{c}-0.169 \\
(-0.886)\end{array}$ & $\begin{array}{c}-0.177 \\
(-0.937)\end{array}$ & $\begin{array}{l}-0.172 \\
(0.836)\end{array}$ \\
\hline $\mathrm{R} 1$ & - & - & $\begin{array}{c}2.027 \\
(3.754)\end{array}$ & $\begin{array}{c}1.995 \\
(3.711)\end{array}$ & $\begin{array}{c}2.046 \\
(23.773)\end{array}$ \\
\hline $\mathrm{R} 2$ & - & - & - & - & - \\
\hline $\mathrm{R} 3$ & - & $\begin{array}{c}1.995 \\
(3.701)\end{array}$ & - & - & - \\
\hline PE1 & - & - & - & - & $\begin{array}{c}0.038 \\
(0.039)\end{array}$ \\
\hline$\overline{\mathrm{R}}^{2}$ & 0.595 & 0.961 & 0.678 & 0.679 & 0.661 \\
\hline D.W. & .1806 & 1.813 & 1.799 & 1.777 & 1.799 \\
\hline F & 300.356 & 316.865 & 10.800 & - & 8.573 \\
\hline SSR & 0.614 & 0.619 & 0.499 & 0.501 & 0.499 \\
\hline
\end{tabular}

1:PE: Expected Inflation Rate. 
Aqdas Ali Kazmi 91

Table-6: Public Saving Functions for Pakistan: 1960-88 (OLS Estimation)

\begin{tabular}{|c|c|c|c|c|c|c|}
\hline & (1) & (2) & (3) & (4) & (5) & (6) \\
\hline $\mathrm{C}$ & $\begin{array}{c}-0.021 \\
(-1.097)\end{array}$ & $\begin{array}{c}0.032 \\
(2.464)\end{array}$ & $\begin{array}{c}0.033 \\
(2.475)\end{array}$ & $\begin{array}{c}0.055 \\
(2.672)\end{array}$ & $\begin{array}{c}-0.017 \\
(-0.619)\end{array}$ & $\begin{array}{c}0.020 \\
(0.741)\end{array}$ \\
\hline $\mathrm{g}$ & $\begin{array}{c}0.073 \\
(0.960)\end{array}$ & $\begin{array}{c}0.93 \\
(1.067)\end{array}$ & $\begin{array}{c}0.107 \\
(1.164)\end{array}$ & $\begin{array}{c}0.138 \\
(1.513)\end{array}$ & $\begin{array}{c}0.076 \\
(0.997)\end{array}$ & $\begin{array}{c}0.152 \\
(1.798)\end{array}$ \\
\hline $\mathrm{X}$ & $\begin{array}{c}-0.020 \\
(-0.199)\end{array}$ & - & $\begin{array}{c}0.066 \\
(0.573)\end{array}$ & - & - & $\begin{array}{c}0.024 \\
(0.221)\end{array}$ \\
\hline M & $\begin{array}{c}0.188 \\
(3.284)\end{array}$ & $\begin{array}{c}0.216 \\
(3.596)\end{array}$ & $\begin{array}{c}0.197 \\
(2.841)\end{array}$ & $\begin{array}{c}0.133 \\
(1.211)\end{array}$ & $\begin{array}{c}0.187 \\
(2.416)\end{array}$ & - \\
\hline $\mathrm{P}$ & $\begin{array}{c}-0.148 \\
(-3.878)\end{array}$ & $\begin{array}{c}-0.139 \\
(-3.693)\end{array}$ & $\begin{array}{c}-0.154 \\
(-3.340)\end{array}$ & $\begin{array}{c}-0.125 \\
(-3.267)\end{array}$ & $\begin{array}{c}-0.147 \\
(-4.394)\end{array}$ & $\begin{array}{c}-0.144 \\
(-2.656)\end{array}$ \\
\hline EXAID & $\begin{array}{l}-0.029 \\
(-0.303)\end{array}$ & $\begin{array}{c}0.009 \\
(0.086)\end{array}$ & $\begin{array}{c}0.034 \\
(0.299)\end{array}$ & $\begin{array}{c}0.098 \\
(0.819)\end{array}$ & - & $\begin{array}{c}0.688 \\
(0.575)\end{array}$ \\
\hline $\mathrm{T}$ & $\begin{array}{c}0.567 \\
(3.284)\end{array}$ & - & - & - & $\begin{array}{c}0.545 \\
(3.112)\end{array}$ & $\begin{array}{c}0.440 \\
(2.160)\end{array}$ \\
\hline $\mathrm{Sp}$ & $\begin{array}{c}-0.491 \\
(-4.613)\end{array}$ & $\begin{array}{l}-0.446 \\
(-4.062)\end{array}$ & $\begin{array}{c}-0.483 \\
(-3.750)\end{array}$ & $\begin{array}{c}-0.482 \\
(-4.376)\end{array}$ & $\begin{array}{c}-0.514 \\
(-5.567)\end{array}$ & $\begin{array}{c}-0.501 \\
(-4.142)\end{array}$ \\
\hline TOT & - & - & - & $\begin{array}{l}-0.0002 \\
(-1.422)\end{array}$ & $\begin{array}{c}0.00003 \\
(0.211)\end{array}$ & $\begin{array}{l}-0.0002 \\
(-2.185)\end{array}$ \\
\hline CAD & - & - & - & - & $\begin{array}{c}-0.078 \\
(-0.986)\end{array}$ & - \\
\hline$\overline{\mathrm{R}}^{2}$ & 0.585 & 0.410 & 0.393 & 0.435 & 0.603 & 0.468 \\
\hline D.W. & 2.487 & 2.060 & 2.119 & 2.240 & 2.418 & 2.030 \\
\hline $\mathrm{F}$ & 6.648 & 4.898 & 4.017 & 4.600 & 7.064 & 4.080 \\
\hline SSR & 0.001 & 0.002 & 0.002 & 0.002 & 0.002 & 0.002 \\
\hline
\end{tabular}


92 The Lahore Journal of Economics, Vol.6, No.2

Table-7: Foreign Saving Functions for Pakistan: 1960-88

DEP: VAR: Current Account Deficit/GNP

(OLS Estimation)

\begin{tabular}{|c|c|c|c|c|c|c|}
\hline & (1) & (2) & (3) & (4) & (5) & (6) \\
\hline C & $\begin{array}{c}0.027 \\
(1.413)\end{array}$ & $\begin{array}{l}-0.021 \\
(0.519)\end{array}$ & $\begin{array}{c}-0.031 \\
(-1.599)\end{array}$ & $\begin{array}{c}0.125 \\
(-3.193)\end{array}$ & $\begin{array}{c}0.017 \\
(0.342)\end{array}$ & $\begin{array}{c}0.127 \\
(3.406)\end{array}$ \\
\hline $\mathrm{YN}$ & $\begin{array}{l}-0.00001 \\
(-0.2771)\end{array}$ & $\begin{array}{l}- \\
-\end{array}$ & - & $\begin{array}{l}- \\
-\end{array}$ & $\begin{array}{c}-0.000001 \\
(-0.267)\end{array}$ & - \\
\hline G & $\begin{array}{l}-0.033 \\
(-0.222)\end{array}$ & $\begin{array}{l}-0.150 \\
(-1.296)\end{array}$ & $\begin{array}{c}-0.162 \\
(-1.524)\end{array}$ & $\begin{array}{c}-0.120 \\
(-0.824)\end{array}$ & $\begin{array}{l}- \\
-\end{array}$ & $\begin{array}{c}0.119 \\
(0.840)\end{array}$ \\
\hline INV/GNP & - & $\begin{array}{c}0.588 \\
(4.314)\end{array}$ & $\begin{array}{c}0.606 \\
(5.128)\end{array}$ & $\begin{array}{l}- \\
-\end{array}$ & $\begin{array}{c}0.539 \\
(5.053)\end{array}$ & - \\
\hline $\begin{array}{l}\text { MOIL/ } \\
\text { GNP }\end{array}$ & - & $\begin{array}{c}-0.286 \\
(-0.933)\end{array}$ & $\begin{array}{c}-0.224 \\
(-1.066)\end{array}$ & $\begin{array}{c}0.89 \\
(0.170)\end{array}$ & $\begin{array}{c}0.142 \\
(0.362)\end{array}$ & - \\
\hline TOT & - & $\begin{array}{l}- \\
-\end{array}$ & $\begin{array}{l}- \\
-\end{array}$ & $\begin{array}{c}-0.011 \\
(-2.599)\end{array}$ & $\begin{array}{l}-0.0004 \\
(-1.442)\end{array}$ & $\begin{array}{c}-0.001 \\
(-2.737)\end{array}$ \\
\hline NFI/GNP & $\begin{array}{l}- \\
-\end{array}$ & - & $\begin{array}{l}- \\
-\end{array}$ & $\begin{array}{c}-0.552 \\
(-1.797)\end{array}$ & $\begin{array}{c}-0.447 \\
(-2.034)\end{array}$ & $\begin{array}{l}-0.517 \\
(-2.333)\end{array}$ \\
\hline $\mathrm{P}$ & $\begin{array}{c}0.108 \\
(2.201)\end{array}$ & $\begin{array}{c}0.175 \\
(4.401)\end{array}$ & $\begin{array}{c}0.170 \\
(4.794)\end{array}$ & $\begin{array}{c}0.145 \\
(2.636)\end{array}$ & $\begin{array}{c}0.151 \\
(3.719)\end{array}$ & $\begin{array}{c}0.150 \\
(3.438)\end{array}$ \\
\hline $\mathrm{E}$ & $\begin{array}{l}- \\
-\end{array}$ & $\begin{array}{c}-0.002 \\
(-1.973)\end{array}$ & $\begin{array}{c}-0.002 \\
(-2.764)\end{array}$ & $\begin{array}{c}-0.004 \\
(-3.011)\end{array}$ & $\begin{array}{c}-0.002 \\
(-1.285)\end{array}$ & $\begin{array}{l}-0.004 \\
(-3.233)\end{array}$ \\
\hline DEF/NGP & $\begin{array}{c}0.355 \\
(2.354)\end{array}$ & $\begin{array}{c}0.072 \\
(0.555)\end{array}$ & $\begin{array}{c}0.060 \\
(0.501)\end{array}$ & $\begin{array}{c}0.300 \\
(2.095)\end{array}$ & $\begin{array}{l}- \\
-\end{array}$ & $\begin{array}{c}0.302 \\
(2.167)\end{array}$ \\
\hline LOG(TOT) & $\begin{array}{l}- \\
-\end{array}$ & $\begin{array}{l}-0.0001 \\
(-2.284)\end{array}$ & $\begin{array}{l}- \\
-\end{array}$ & $\begin{array}{l}- \\
-\end{array}$ & $\begin{array}{l}- \\
-\end{array}$ & - \\
\hline$\overline{\mathrm{R}}^{2}$ & 0.464 & 0.741 & 0.752 & 0.576 & 0.765 & 0.595 \\
\hline D.W. & 1.898 & 1.021 & 1.045 & 1.877 & 1.928 & 1.859 \\
\hline $\mathrm{F}$ & 7.052 & 12.426 & 15.115 & 6.435 & 14.012 & 7.849 \\
\hline SSR & 0.007 & 0.003 & 0.003 & 0.004 & 0.003 & 0.005 \\
\hline
\end{tabular}


Aqdas Ali Kazmi 93

Table-8: Domestic Saving Functions for Pakistan: 1960-88 (OLS Estimation)

\begin{tabular}{|c|c|c|c|c|c|}
\hline & (1) & (2) & (3) & (4) & (5) \\
\hline $\mathrm{C}$ & $\begin{array}{l}-0.898 \\
(-1.96)\end{array}$ & $\begin{array}{c}-0.780 \\
(-1.835)\end{array}$ & $\begin{array}{c}-1.020 \\
(-2.357)\end{array}$ & $\begin{array}{c}-33.5802 \\
(-2.999)\end{array}$ & $\begin{array}{c}-0.997 \\
(-1.699)\end{array}$ \\
\hline $\log (Y)$ & $\begin{array}{c}0.949 \\
(2.127)\end{array}$ & $\begin{array}{c}0.62 \\
(1.499)\end{array}$ & $\begin{array}{c}0.091 \\
(2.210)\end{array}$ & $\begin{array}{c}0.136(\mathrm{Y}) \\
(3.113)\end{array}$ & $\begin{array}{c}0.108 \\
(1.615)\end{array}$ \\
\hline G & - & - & - & $\begin{array}{c}131.994 \\
(2.025)\end{array}$ & $\begin{array}{l}- \\
-\end{array}$ \\
\hline LFPR & $\begin{array}{c}1.274 \\
(2.044)\end{array}$ & $\begin{array}{c}1.315 \\
(2.237)\end{array}$ & $\begin{array}{c}1.702 \\
(2.746)\end{array}$ & $\begin{array}{c}924.399 \\
(3.048)\end{array}$ & $\begin{array}{c}1.107 \\
(1.751)\end{array}$ \\
\hline $\mathrm{X}$ & - & $\begin{array}{c}0.249 \\
(1.541)\end{array}$ & $\begin{array}{c}0.338 \\
(2.034)\end{array}$ & $\begin{array}{c}0.332 \\
(2.246)\end{array}$ & $\begin{array}{l}- \\
-\end{array}$ \\
\hline M & $\begin{array}{c}0.073 \\
(0.487)\end{array}$ & $\begin{array}{c}0.27 \\
(0.186)\end{array}$ & $\begin{array}{c}-0.101 \\
(-0.616)\end{array}$ & $\begin{array}{c}-0.240 \\
(-1.559)\end{array}$ & $\begin{array}{l}- \\
-\end{array}$ \\
\hline $\mathrm{P}$ & - & - & - & - & $\begin{array}{l}-9,249 \\
(-4.214\end{array}$ \\
\hline EXAID & $\begin{array}{c}0.260 \\
(1.500)\end{array}$ & - & $\begin{array}{c}0.341 \\
(2.043)\end{array}$ & $\begin{array}{l}- \\
-0\end{array}$ & $\begin{array}{c}0.055(\mathrm{a}) \\
(0.352)\end{array}$ \\
\hline $\mathrm{T}$ & - & $\begin{array}{c}0.532 \\
(\mathrm{a} 2.035)\end{array}$ & - & $\begin{array}{c}0.439 \\
(1.883)\end{array}$ & $\begin{array}{l}- \\
-\end{array}$ \\
\hline $\mathrm{R} 1$ & $\begin{array}{l}0.0186 \\
(2.045)\end{array}$ & $\begin{array}{c}0.210 \\
(3.535)\end{array}$ & $\begin{array}{c}0.195 \\
(3.238)\end{array}$ & $\begin{array}{l}81.092 \\
(2.131)\end{array}$ & $\begin{array}{l}- \\
-\end{array}$ \\
\hline NFI & $\begin{array}{c}-1.205 \\
(-5.009)\end{array}$ & $\begin{array}{c}1.196 \\
(-5.442)\end{array}$ & $\begin{array}{c}-1.112 \\
(-4.844)\end{array}$ & $\begin{array}{c}-0.966 \\
(-5.457)\end{array}$ & $\begin{array}{c}-0.927 \\
(-4.088)\end{array}$ \\
\hline G & - & - & - & - & $\begin{array}{c}0.272 \\
(2.587)\end{array}$ \\
\hline CARS & - & - & - & - & $\begin{array}{c}-0.015 \\
(-1.581)\end{array}$ \\
\hline$\overline{\mathrm{R}}^{2}$ & 0.822 & 0.844 & 0.845 & 0.765 & 0.867 \\
\hline D.W. & 1.766 & 1.433 & 1.686 & 1475 & 2.231 \\
\hline $\mathrm{F}$ & 22.541 & 22.633 & 22.667 & 22.369 & 23.903 \\
\hline SSR & 0.003 & 0.030 & 0.003 & 984.043 & 0.002 \\
\hline
\end{tabular}


94 The Lahore Journal of Economics, Vol.6, No.2

Table-9: National Saving Functions for Pakistan: 1960-88 (OLS Estimation)

\begin{tabular}{|c|c|c|c|c|c|}
\hline & (1) & (2) & (3) & (4) & (5) \\
\hline \multirow[t]{2}{*}{$\mathrm{C}$} & -0.922 & -0.745 & -341.022 & -365.978 & -319.542 \\
\hline & $(-2.612)$ & $(-2.160)$ & $(-3.215)$ & $(-3.231)$ & $(-2.680)$ \\
\hline \multirow[t]{2}{*}{$\log Y$} & 0.080 & 0.057 & - & - & - \\
\hline & $(2.565)$ & $(1.905)$ & & & \\
\hline \multirow[t]{2}{*}{ Y } & - & - & 0.139 & 0.167 & 0.1390 \\
\hline & & & $(3.589)$ & $(3.722)$ & $(2.564)$ \\
\hline \multirow[t]{2}{*}{ G } & 0.205 & 0.169 & 132.635 & - & 153.256 \\
\hline & $(2.024)$ & $(1.675)$ & $(2.086)$ & & $(2.092)$ \\
\hline \multirow[t]{2}{*}{ LFPR } & 1.577 & 1.294 & 934.477 & 1013.749 & 941.453 \\
\hline & $(2.863)$ & $(2.355)$ & $(3.203)$ & $(3.272)$ & $(2.763)$ \\
\hline \multirow[t]{2}{*}{$\mathrm{X}$} & 0.374 & 0.530 & 0.323 & 0.347 & 0.367 \\
\hline & (2.489) & $(2.704)$ & (2.349) & (2.389) & $(2.230)$ \\
\hline \multirow[t]{2}{*}{ M } & -0.180 & -0.125 & -0.222 & -0.201 & -0.276 \\
\hline & $(-1.44 \&)$ & $(-0.925)$ & $(-0.873)$ & $(-1.653)$ & $(-1.588)$ \\
\hline \multirow[t]{2}{*}{$P$} & - & - & - & - & -72.113 \\
\hline & & & & & $(-1.741)$ \\
\hline \multirow[t]{2}{*}{ EXAID } & 0.374 & - & - & 0.312 & - \\
\hline & $(2.576)$ & & & (1.576) & \\
\hline \multirow[t]{2}{*}{ CAD } & - & 0.070 & - & - & 0.455 \\
\hline & & $(0.417)$ & & & $(2.030)$ \\
\hline \multirow[t]{2}{*}{$\mathrm{T}$} & - & - & 0.432 & 0.164 & - \\
\hline & & & $(1.920)$ & (0.614) & \\
\hline \multirow[t]{2}{*}{ R1 } & 0.166 & 0.210 & 83.3267 & 104.192 & - \\
\hline & $(3.070)$ & $(3.690)$ & $(2.355)$ & $(2.911)$ & \\
\hline \multirow[t]{2}{*}{ G } & - & 0.257 & - & - & - \\
\hline & & (2.729) & & & \\
\hline \multirow[t]{2}{*}{ CARS } & - & - & - & - & 1.947 \\
\hline & & & & & $(-0.251)$ \\
\hline$\overline{\mathbf{R}}^{2}$ & 0.723 & 0.734 & 0.943 & 0.938 & 0.941 \\
\hline D.W. & 1.696 & 1.974 & 1.525 & 1.773 & 1.590 \\
\hline $\mathrm{F}$ & 11.418 & 10.668 & 66.826 & 61.687 & 50.390 \\
\hline SSR & 0.003 & 0.002 & 985.846 & 1064.170 & 922.673 \\
\hline
\end{tabular}

Notes: * The starred equations are in the real per capita terms, rather than in ratio form. 
Aqdas Ali Kazmi 95

Table-9 (Contd.): National Saving Function for Pakistan: 1960-88 (OLS Estimation)

\begin{tabular}{|c|c|c|}
\hline & (6) & (7) \\
\hline $\mathrm{C}$ & $\begin{array}{c}-0.926 \\
(-1.594)\end{array}$ & $\begin{array}{c}-306.911 \\
(-2.569)\end{array}$ \\
\hline $\operatorname{LOG}(\mathrm{Y})$ & $\begin{array}{c}-/-02 \\
(1.388)\end{array}$ & - \\
\hline $\mathrm{Y}$ & - & $\begin{array}{c}0.136 \\
(2.490)\end{array}$ \\
\hline LFPR & $\begin{array}{c}1.126 \\
(1.694)\end{array}$ & $\begin{array}{c}832.912 \\
(2.533)\end{array}$ \\
\hline $\mathrm{X}$ & $\begin{array}{c}0.566 \\
(3.194)\end{array}$ & $\begin{array}{c}0.302 \\
(1.949)\end{array}$ \\
\hline M & - & $\begin{array}{c}-0.316 \\
(-1.135)\end{array}$ \\
\hline$P$ & $\begin{array}{c}-0.244 \\
(-5.545)\end{array}$ & $\begin{array}{l}-88.102 \\
(-2.251)\end{array}$ \\
\hline EXAID & $\begin{array}{c}-0.181 \\
(-0.760)\end{array}$ & - \\
\hline $\mathrm{T}$ & $\begin{array}{c}0.293 \\
(1.081)\end{array}$ & $\begin{array}{c}0.491 \\
(2.197)\end{array}$ \\
\hline G & $\begin{array}{c}0.361 \\
(2.002)\end{array}$ & - \\
\hline CARS & $\begin{array}{l}-0.0001 \\
(-1.692)\end{array}$ & $\begin{array}{l}-1.552^{*} \\
(-0.199)\end{array}$ \\
\hline TOT & $\begin{array}{l}-0.0001 \\
(-0.499)\end{array}$ & - \\
\hline NFI & $\begin{array}{c}0.394 \\
(0.152)\end{array}$ & - \\
\hline$\overline{\mathrm{R}}^{2}$ & 0.745 & 0.940 \\
\hline D.W. & 2,241 & 1,539 \\
\hline $\mathrm{F}$ & 9.169 & 55.812 \\
\hline SSR & 0.022 & 983.757 \\
\hline
\end{tabular}

(*) Cars variable here is entered as cars per head (i.e. CARS/POP). 


\section{References}

Abe, S., M. J. Fry., B. K. Min., P. Vongvipanond., and T. P. Yu., 1977, "Financial Liberalization and Savings in Economic Development: An Empirical Test for Six Countries", The Pakistan Development Review. Vo1. 16, No. 3, pp. 298-308.

Abraham, I.W., 1964, "Saving Patterns in Latin America", Economic Development and Cultural Change, Vo1. 12, No. 4, pp. 377-391.

Aghevli, Bijan B., James M. Boughton., Peter J. Montiel., Delano Villanueva., and Geoffrey Woglom., 1990,"The Role of Natural Saving in the World Economy: Recent Trends and Prospects", Occassional Paper, No. 67. International Monetary Fund, Washington, D.C., pp. 1-64.

Ahmed S., 1990, "Foreign Capital Inflow and Economic Growth: A Two-Gap Model for the Bangladesh Economy”, The Bangladesh/Development Studies 18:1.

Aslam, Naheed., 1987, “The Impact of Foreign Capital Inflow on Savings and Investment: The Case of Pakistan", The Pakistan Development Review, Vo,. 26, No. 4, pp. 787-789.

Barro, Robert J., 1978, "The Impact of Social Security and Private Saving: Evidence from the US Time Series, Washington D.C., American Enterprise Institute.

Bazdarich, M.J., 1978, "Optimal Growth and Stages in the Balance of Payments”, Journal of International Economics, Vo1. 8, pp. 825-443.

Bilquees, Faiz, 1993, Comments on "National Saving Rates of India and Pakistan: A Macroeconometric Analysis”, paper by Aqdas Ali Kazmi, The Pakistan Development Review, Vol., 32, No. 4.

Boskin, Michael, J., Fleming, John S., and Gorini Stefano., (Ed), 1987, Private Saving and Public Debt. Basil Blackwell, Oxford, (U.K.).

Chenery, H.B. (Ed) and MacEwan., 1966, "Optimal Patterns of Growth and Aid, The Case Study for Pakistan”, The Pakistan Development Review, Vol. 6, No. 2,.

Chenery, H.B. (Ed) and A.M. Strout., 1966, "Foreign Assistance and Economic Development”, The American Economic Review, Vol. 56, pp. 679.733. 
Chenery, H.B. (Ed) and A.M. Strout., 1968, "Foreign Assistance and Economic Development: Replay", The American Economic Review, Vol. 58, Pp. 912-916.

Chishti, S., and M. Aynul Hasan, 1992, "Foreign Aid, Defence Expenditure and Public Investment in Pakistan”, The Pakistan Development Review, 31:4.

Feldstein Martin., 1974, "Social Security and Saving: The Extended Life Cycle Theory”, The American Economic Review, Vo1. 66 (2), pp. 77-87.

Fry, Maxwell J., 1991, "Domestic Resource Mobilization in Developing Asia: Four Policy Issues”, The Asian Development Review, 9:1.

Giovannini, Alberto., 1985, "Saving and Real Interest Rate in LDCs", Journal of Development Economics, Vo1. 18, pp. 197-217.

Goldsmith, R.W., (ed.)., 1966, “A Study of Savings in the US”, Vol. I. II. And II. (Princeton University Press, Princeton).

Graham, John W., (1987, "International Differences in Savings Rates and the Life Cycle Hypothesis”, The European Economic Review, Vol. 31, pp. 1509-1529.

Greenway, D., 1980, “Trade Taxes, as a Source of Government Revenues: An International Comparison", The Scottish Journal of Political Economy, Vol. 27, pp. 175-182.

Griffen, K.B., and J.L. Enos, 1970, "Foreign Assistance: Objective and Consequences”, Economic Development and Cultural Change 18:3.

Gupta, K.1., 1970, "Foreign Capital and Domestic Savings: A test of Haavelmo's Hypothesis with Cross Series Data: A Comment", The Review of Economics and Statistics, Vo1. 52, pp. 214-216.

-----------., 1970, "Personal Saving in Developing Nations: Further Evidence”, The Economic Record.

--------., 1987, “Aggregate Savings, Financial Intermediation and Interest Rates”, The Review of Economic and Statistics, Vol. 69, pp. 301-11. , and M.A. Islam, 1983, Foreign Capital Savings and Growth. 
Halevi, N., 1971, "An Empirical Test of the Balance of Payments Stages Hypothesis", The Journal of International Economics, Vo1. 1, pp 103-108.

Hinrichs, H., 1965, "Determinants of Government Revenue Shares Amongst Less Developed Countries”, Economic Journal, Vo1. 75, pp. 546-556.

Houthakker, 1965, H.S., "On Some Determinants of Savings in the Developed and Underdeveloped Countries”, in E.A.G. Robinson, (Ed.), Problems of Economic Development, London, pp. 212-330.

Hubbard, G.R., 1984, "Precautionary Saving Revisited: Social Security, Individual Welfare and Capital Stock", NBER Working Paper 1430, Cambridge, Mass., National Bureau of Economic Research.

Kazmi, Aqdas Ali, 1975, Rupee Devaluation of Pakistan: Problems and Prospects, Progressive Publishers, Lahore (Third Edition).

----------., 1991, “Savings, Consumption and Ricardian Equivalence: Macroeconometric Analysis of Pakistan: 1960-88”, Ph.D. Dissertation, Boston University, USA.

., 1992, "Ricardian Equivalence' Some Macroeconometric Tests for Pakistan", The Pakistan Development Review, Papers and Proceedings, Eighth Annual General Meeting of Pakistan Society of Development Economists, Islamabad, Vo1. 31, No. 4.

., 1993, "National Saving Rates of India and Pakistan: A Macroeconometric Analysis", The Pakistan Development Review, Papers and Proceedings of Ninth Annual General Meeting of the Pakistan Society of Development Economists, Islamabad, Vol. 32, No. 4.

--., 1994, "Private Consumption, Government Spending and Debt Neutrality: Resolving Kormendi-Feldstein-Modigliani Controversy", The Pakistan Development Review, Papers and Proceedings of Tenth Annual General Meeting of Pakistan Society of Development Economists, Islamabad, Vol. 33, No. 4.

----------., 1995, "Econometric Estimation of Tax-Discounting in Pakistan", The Pakistan Development Review, Papers and Proceedings of Eleventh Annual General Meeting of Pakistan Society of Development Economists, Islamabad, Vol. 34, No. 4. 
Khan, A.H., 1988, "Financial Repression, Financial Development and Structure of Savings in Pakistan”, The Pakistan Development Review, Papers and Proceedings, Vo1. 27, No. 4, pp. 701-719.

Khan, A.H., 1992, "Dependency Ratio, Foreign Capital Inflow and the Rate of Savings in Pakistan”, The Pakistan Development Review 31:4.

Khan N.Z. and Eric Rahim, 1993, "Foreign Aid, Domestic Savings and Economic Growth (Pakistan 1960-88). Paper presented at the $9^{\text {th }}$ Annual General Meeting of the PSDE.

Kotlikof, Lawrence, J., 1989, What Determines Savings?, The MIT Press, Cambridge, Massachusetts.

Levy, V., 1984, "The Saving Gap and the Productivity of Foreign Aid in Devleoping Country: Egypt”, The Journal of Developing Areas, Vol.

Lewis, S., 1963, "Government Revenue From Foreign Trade: An International Comparison”, Manchester School of Economic \& Social Studies, Vo1. 31, pp. 39-64.

Mahmood, S. and Muhammad Ali Qasim, 1992, "Foreign Trade Regimes and Savings sin Pakistan”, The Pakistan Development Review 31:4.

Morisset, J., 1989, "The Impact of Foreign Capital Inflows on Domestic Savings Reexamined: The Case of Argentina", The World Development Review 17:1.

Mosley, P., 1980, "Aid, Savings and Growth Revisited" The Oxford Bulletin of Economics and Statistics, Vol. 42, pp. 79-95.

Hudson, J. and Horrell, S., 1987, “Aid, The Public Sector and the Market in Less Developed Countries", The Economic Journal, Vol. 97, pp. 616-614.

Musgrave, R., 1969, Fiscal System, Yale, Yale University Press.

Nam, Sang-Woo., 1990, "A Sectoral Accounting Approach to National Savings Applied to Korea”, Journal of Development Economics, Vol. 33 , pp. 31-51.

Niazi, M.K., 1984, "Growth in South Asia”, Unpublished Ph.D. Dissertation, Boston University, Boston. 
100 The Lahore Journal of Economics, Vol.6, No.2

Panchamuki, V.R., Rajish Mehta and G.A. Tadads, 1987, "Savings, Investment and Trade" in the Third World, New Delhi: Research and Information System for the Non-Aligned and other Developing countries.

Papanek, Gustav F., 1972, "The Effects of Aid and Other Resource Transfers on Savings and Growth in Less Developed Countries", The Economic Journal, Vo1. 82, pp. 934-50.

---------., 1973, “Aid, Foreign Private Investment, Savings and Growth in Less Developed Countries”, The Journal of Political Economy, Vol. 81, No. 1, pp. 120-130.

---------, 1973, "The Effect of Foreign Aid and Private Investment on Savings and Growth”, Seoul: Korean Development Institute.

Park, Y.C., 1987, "Financial Repression, Liberalization, and Development in Developing Countries”, Korean Development Institute. (KDI Working Paper No. 8704.)

Please, S., 1967, "Savings Through Taxation - Mirage of Reality", Finance and Development, No. 4, pp. 1-10.

Qureshi, Zia, M., 1980, "Saving in Pakistan, 1950-77: Estimation and Analysis”, Unpublished D. Phill Thesis, University of Oxford.

----., 1983, "Household Saving In Pakistan: Some Findings From Time-Series Data”, The Pakistan Development Review, Vo1. 20, No. 2, pp. 73-96.

-., 1985, "Determinants of Corporate Saving in Pakistan: A Macroeconometric Analysis”, The Pakistan Development Review, Vo1. 22, No. 2, pp. 73-96.

Rosenstein Rodan, P.N., 1961, "International Aid for Developing Countries", The Review of Economics and Statistics 43:2.

Sachs, Jaffery, 1983, "Aspects of the Current Account Behaviour of OECD Economies”, Chapter 5, in E. Classen and P. Salin (Ed), Recent Issues in the Theory of Flexible Exchange Rates. North-Holland Publishing Company, pp. 101-122.

, 1981, "The Current Account and Macroeconomic Adjustment in the 1970s”, Brookings Papers on Economic Activity, Vol. 1, pp. 201-268. 
Shabbir, T., and Azhar Mahmood, 1992, "The Effect of Foreign Private Investment on Economic Growth in Pakistan", The Pakistan Development Review 31:4.

Singh, S.K., 1975, "The Determinants of Aggregate Savings”, in S.K. Singh, Development Economics --- Some Findings. Lexington, Massachusetts, Lexington Books.

Swamy, S., 1968, “A Dynamic Personal Savings Function and its Long-Run Implications", The Review of Economics and Statistics, Vol. 50, pp. 112-22.

United Nations, 1981, 1984 and 1986, "Savings for Development: Report of International Symposium on Mobilization of Personal Savings in Developing Countries”, Vol. I, II and III, New York.

Wasow, B., 1979, "Saving and Dependence with Externally Financed Growth", The Review of Economics and Statistics 61:1.

Weisskopf, Thomas E., 1972, "The Impact of Foreign Capital Inflow on Domestic Savings in Undeveloped Countries", The Journal of International Economics, No. 2, pp. 25-38.

Zaidi, Iqbal, M., 1985, "Savings, Investment, Fiscal Deficits and the External Indebtedness of Developing Countries”, World Development, Vo1. 14, No. 5, pp. 573-588. 